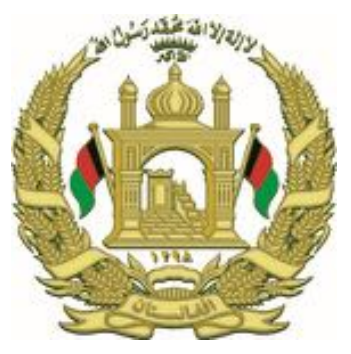

Islamic Republic of Afghanistan

State Ministry for Disaster Management and Humanitarian Affairs

Directorate of Mine Action Coordination

Mine Action Programme of Afghanistan

\title{
National Mine Action Strategic Plan 1395-1399 (2016-2020)
}
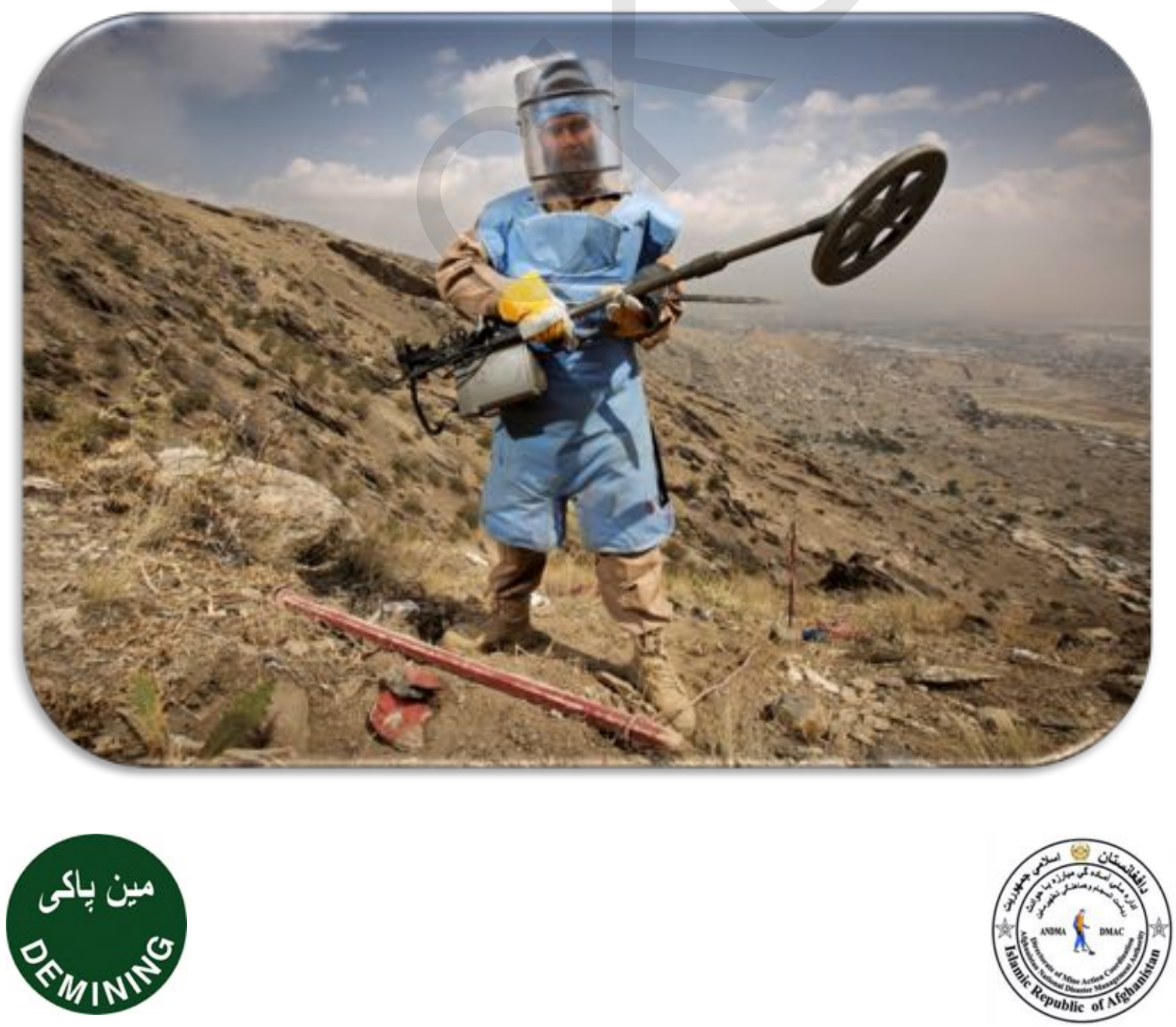


\section{Foreword}

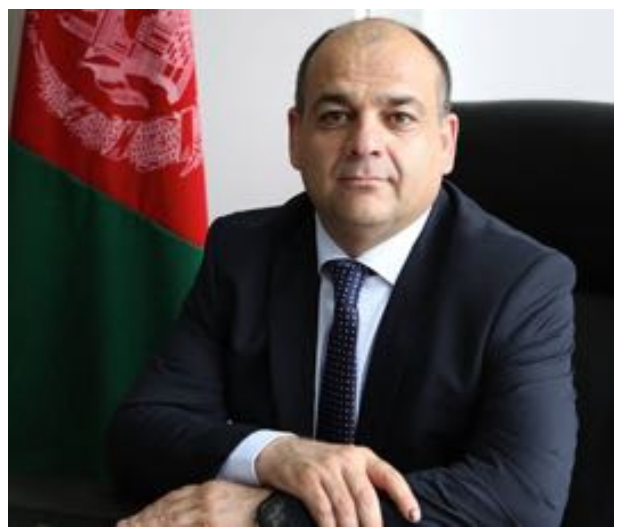

In the name of Almighty Allah, the most Merciful, the most Compassionate.

The National Mine Action Strategic Plan for 1395-1399 (2016-2020), has been developed in consultation with all the relevant mine action implementing partners, including the United Nations, government line ministries, international donors and other stakeholders. The 2016 -2020 plan is in line with all national and international policies, plans and treaties.

This is the first mine action strategic plan that has been developed in close cooperation with all the contributing partners and is based on the actual experiences that exist in the country today. The Mine Action Plan integrates other sectors which benefit from mine action activities and will also link development and economic growth improvement through the work undertaken over the next five years.

The four main goals are: 1). Facilitating Development, 2). Engagement with other Sectors, 31). Mine Action Preventive Functions, 3-2). Mine Action Responsive Functions, and 4). Gender and Diversity Mainstreaming.

As State Minister for Disaster Management and Humanitarian Affairs I endorse the National Mine Action Strategic Plan 2016-2021, and request all relevant partners and stakeholders to use the plan as a roadmap for their ongoing activities.

Wais Ahmad Barmak

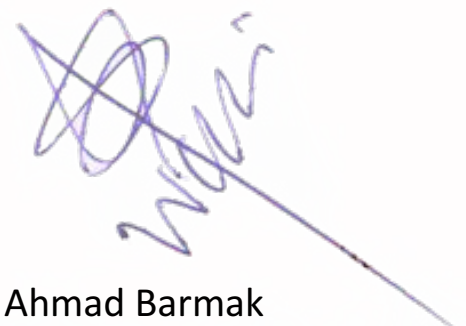

State Minister for Disaster Management and Humanitarian Affairs

Islamic Republic of Afghanistan 


\section{MAPA Stakeholder Commitments}

This document results from the collaborative efforts of the Mine Action Programme of Afghanistan stakeholders. We actively participated in the preparation workshops, discussions or reviewed the document entirely.

To the best of our collective knowledge the strategic goals and objectives outlined in this document reflects the programme strategy for next five years. We therefore commit to play our part in achieving these strategic goals and the objectives.

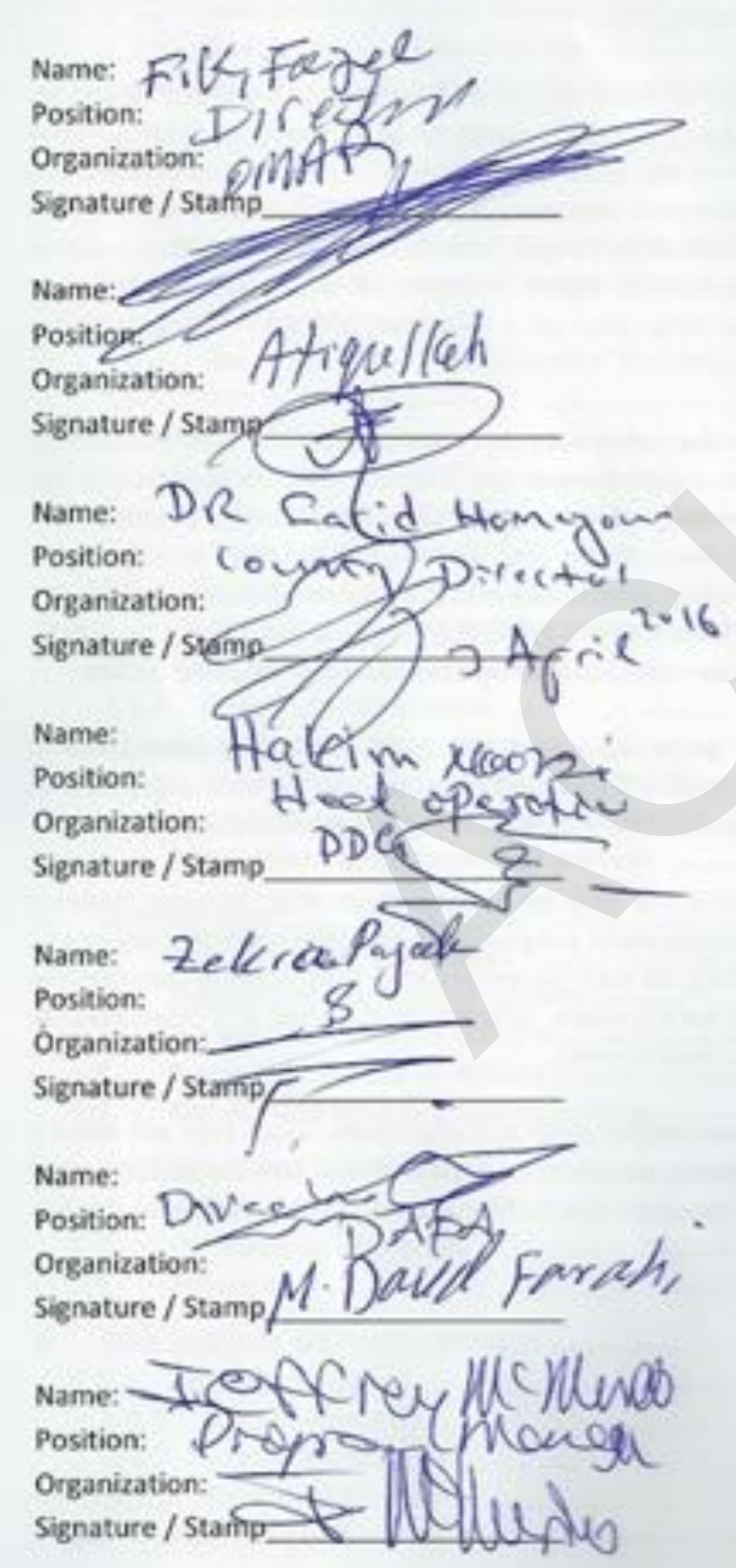

Name: EDS M WAKII Position: $Q 1 C / C O S$ Name: Mohammid shcheb Hetom organization: Mine Dretedy i Pirecta Signature / Stamp

Name: kefayatullah Position: DizeC Tor Organization: ATC Signature / Stamp

Name: Itafi ondra Kün naned Position: Dílector, AO Organization: Signature / Stamp

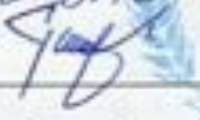

Name: Mohammad Naseem Position: Program coordinater Organization: AABRA R\& Nignature / Stamp
Pame:
Organization: Signature / Stamp

Name: Mohammad shafig Yosuf; Organization: $\mathrm{DM} A \mathrm{C}$

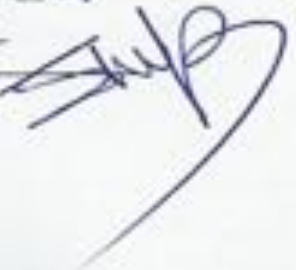




\section{Overview}

Afghanistan has the oldest of the internationally supported humanitarian mine action programmes in the world. It was one of the most heavily landmine contaminated countries, it has suffered from extensive periods of insecurity and natural disaster, and it offers a range of challenging geographical and climatic environments. Despite such challenging circumstances Afghanistan has achieved outstanding results in its battle against landmines and explosive remnants of war (ERW), and remains committed to fulfilling its commitment under Article $V$ of the Anti-Personnel Mine Ban Treaty (APMBT) or "the Ottawa Treaty" to remove all known areas contaminated by the weapon. Those same circumstances mean that the country requires continuing international support to ensure it achieves its objectives and meets its obligations.

Afghanistan has led the way in many aspects of mine action and intends to continue doing so. Perhaps the greatest challenge faced by the Mine Action Programme of Afghanistan (MAPA)-and by other such programmes around the world - is the need to demonstrate credibly and consistently that mine action is worth the significant resources it requires. In the past the implicit assumption has often been that mine action is, in and of itself, always a good thing. More recently it has become clear that dealing with the current and potential future impacts of landmines, unexploded ordnance (UXO) and other ERW represents only one of a number of tasks facing national governments and their international supporters.

Mine action programmes today need to show that what they do is not only worthwhile, but is more worthwhile than other possible activities that a government can consider. A typical response has been to attempt to increase the understanding of mine action within broader development programmes and agencies - mainstreaming mine action into development. This strategic plan reflects a clearer, more demanding understanding: that future success and sustainability within the MAPA will only be achieved if mine action increases its understanding of, and ability to satisfy, development needs, expectations and principles - mainstreaming development into mine action.

That aspiration is reflected in the strategic goals set out in this plan: facilitating development; engaging with other sectors; taking action to reduce the impact of mines and ERW; taking action to mitigate the consequences of mine and ERW accidents; and mainstreaming gender and diversity.

It is the aspiration of the MAPA that it should not only be able to claim that its work makes a difference, but that government agencies, development programmes and international donors and institutions should all be convinced of that fact, to such an extent that they actively demand the services and support of the MAPA. In pursuing such a vision, reflected in the goals and objectives set out in this plan, the MAPA once again seeks to lead the way.

This plan sets out challenging, relevant and meaningful goals and objectives. Ones that will make a significant difference to the social and economic situation in Afghanistan. But the MAPA cannot achieve everything on its own. It needs and requests the further support of international donors, agencies and partners. 


\section{Table of Contents}

Introduction

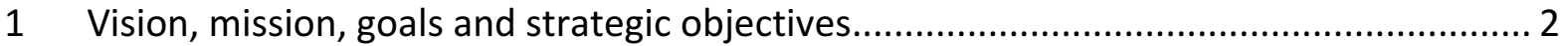

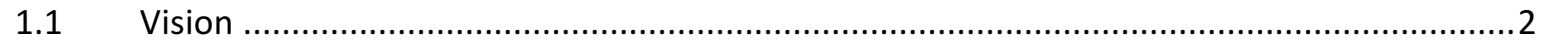

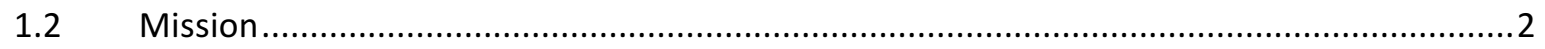

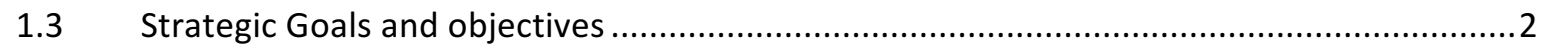

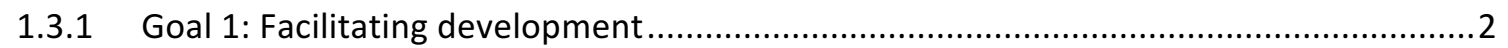

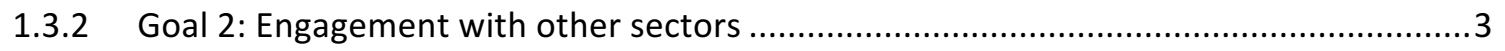

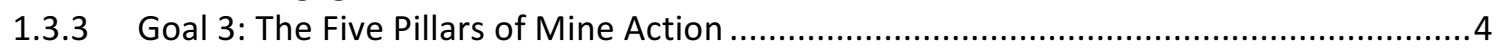

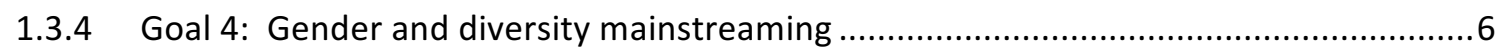

2 NMASP development, approval and endorsement.................................................. 7

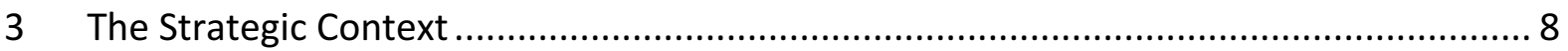

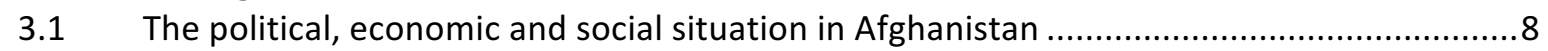

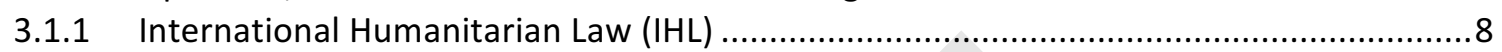

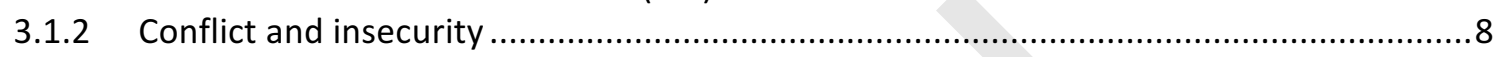

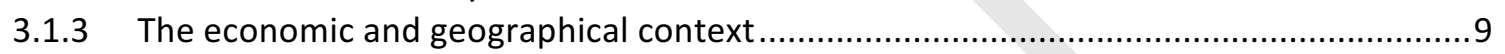

3.1.4 International support ............................................................................

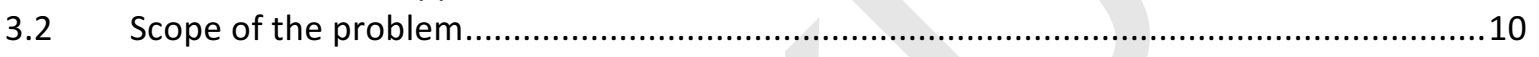

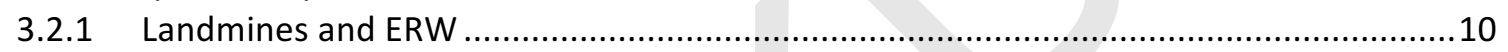

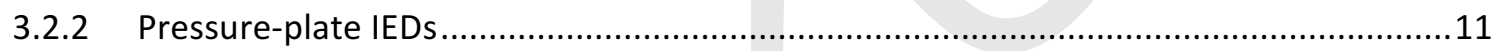

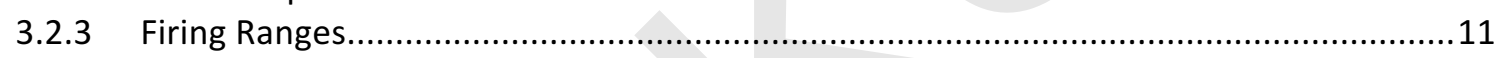

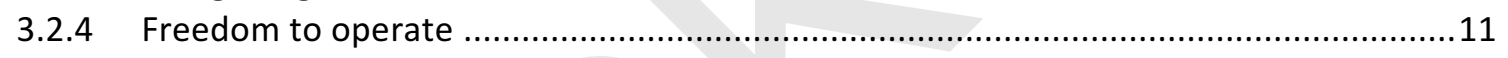

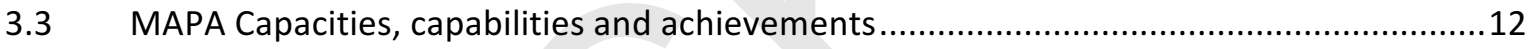

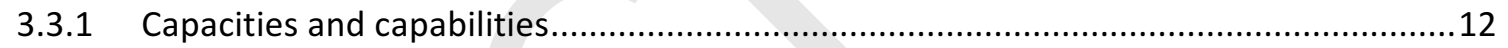

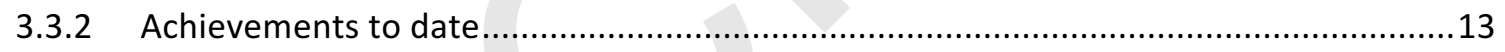

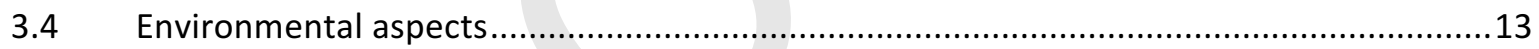

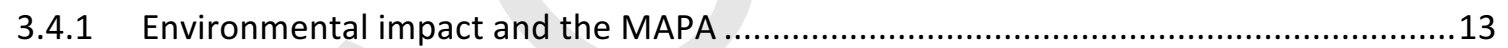

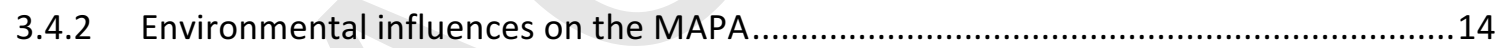

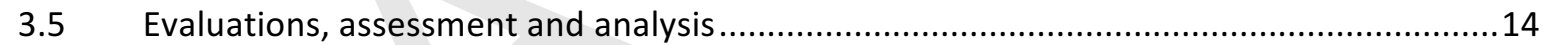

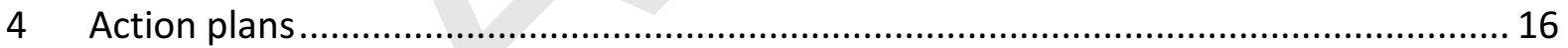

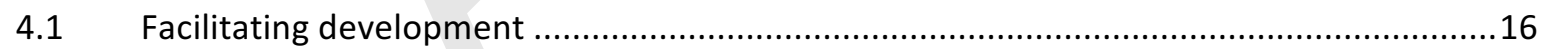

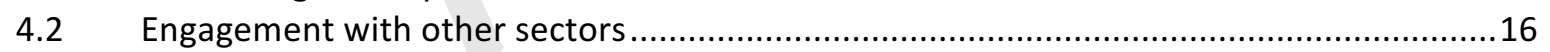

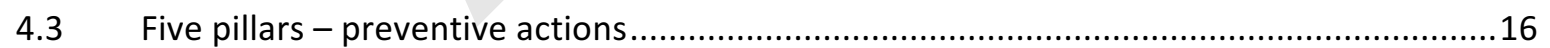

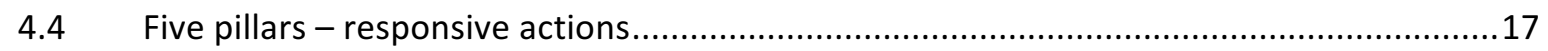

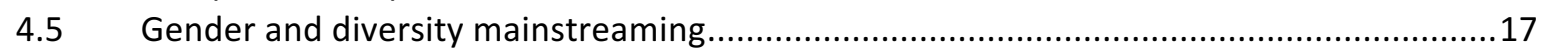

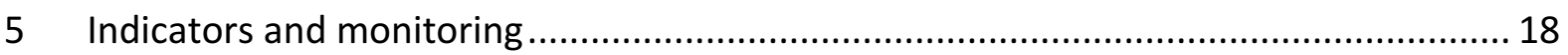

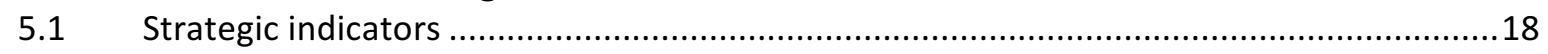

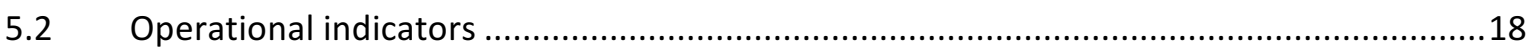

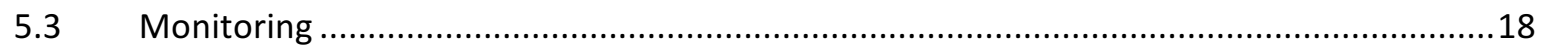

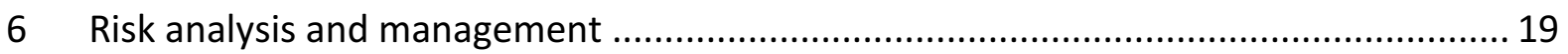

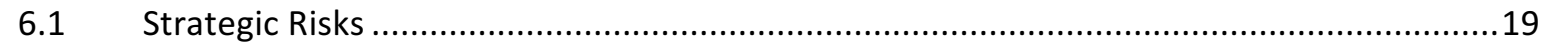

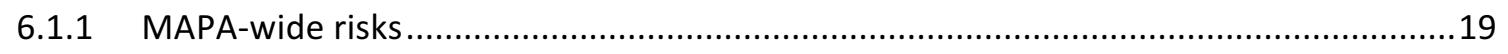

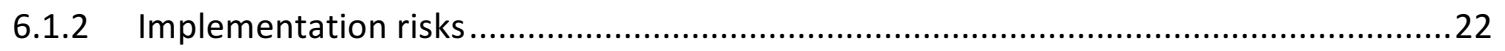

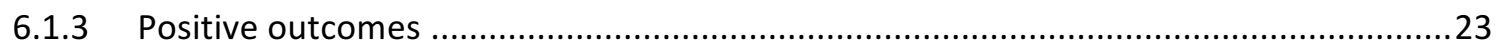

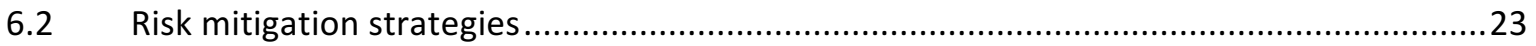

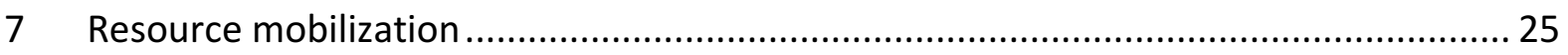

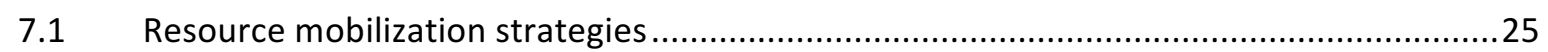




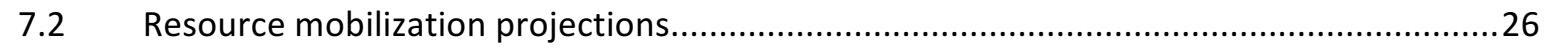

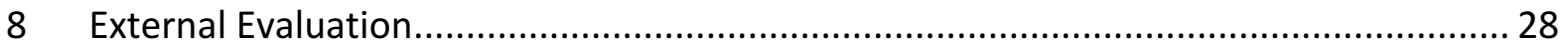

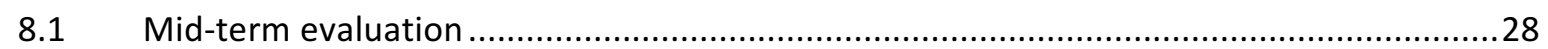

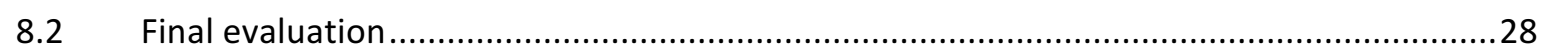

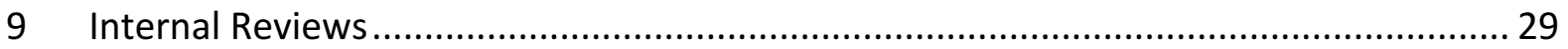

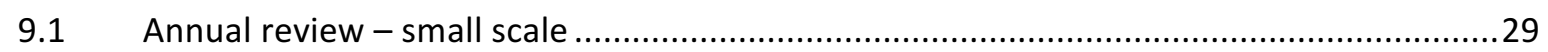

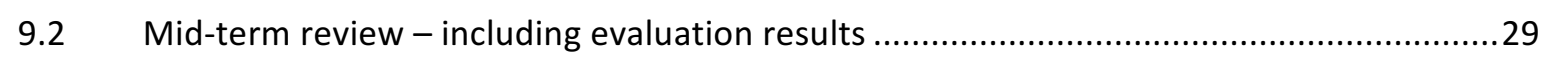

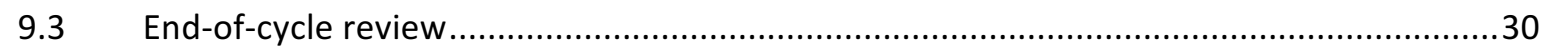

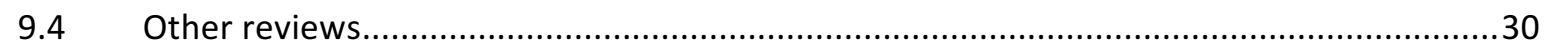

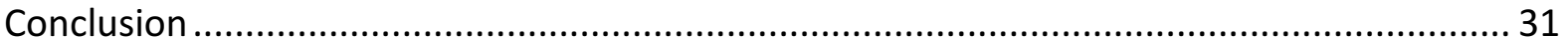

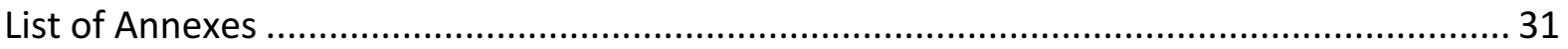

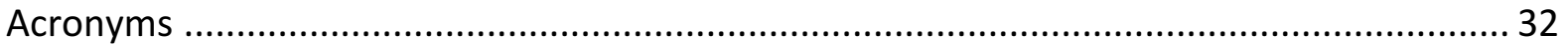

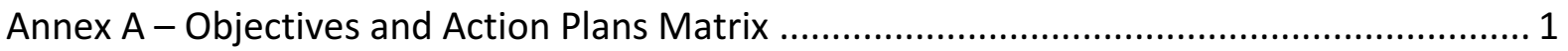

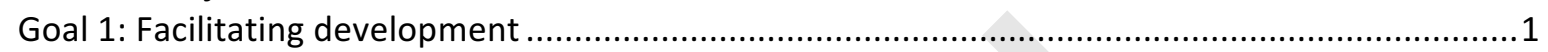

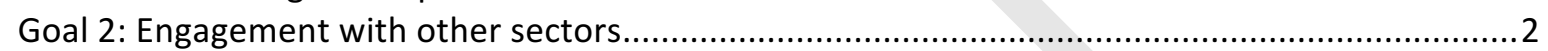

Goal 3-1: Preventive action to reduce the impact of mines and ERW ..........................................4

Goal 3-2: Responsive actions to mitigate the consequences of mine and ERW accidents ...............6

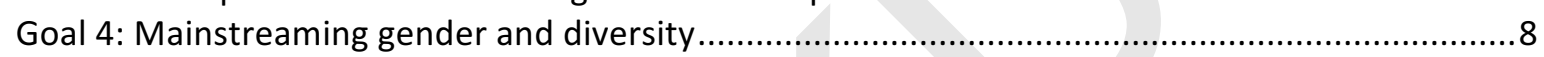

Annex B - Stakeholder participants in the strategic planning process ................................. 1

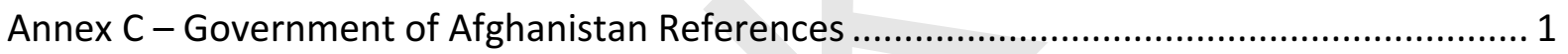

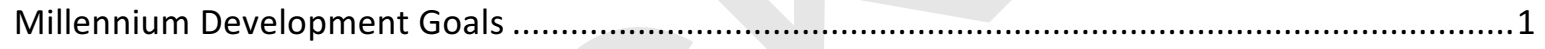

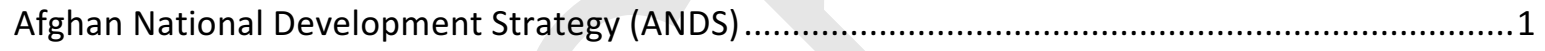

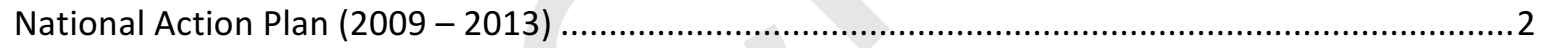

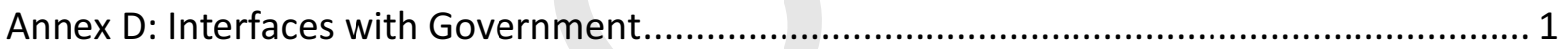




\section{Introduction}

The Mine Action Programme of Afghanistan is both one of the pre-eminent examples of a successful mine action programme (MAP) and an illustration of the current issues that face global mine action. The most significant trend nationally and globally is that of reduced donor support to mine action: in some cases, reduced levels of funding; in others, sustained levels of funding but spread over a wider range of activities. In either case the result is a climate in which it is harder to obtain funds to sustain mine action activities at their previous levels.

The factors influencing this trend are numerous. Some of the most significant include: a perception that landmines are a problem that has, to a great extent, been addressed; concern amongst donors that some historical mine action work did not lead to results that justified the level of funding; general reductions in donor funding levels in light of the global economic situation; and greater demands within donor governments for justification of spending.

The MAPA recognizes and accepts the reality of the situation it faces. This national mine action strategic plan (NMASP) reflects the context in which it will be implemented and faces up to the reality and challenges within Afghanistan and the wider world. In particular, this NMASP recognizes the need for the MAPA to demonstrate that the work it does is necessary for the development of Afghanistan, that it is implemented efficiently, and that the onus is on the MAPA to persuade other stakeholders of the programme's worth and importance; not to assume that others will automatically reach such a conclusion.

At the same time Afghanistan has important obligations under the Ottawa Treaty; obligations that it cannot be expected to reach without international support. Afghanistan has always been a strong supporter of the campaign to ban landmines, and recognizes the benefits that have accrued from global stigmatization of these indiscriminate and long-lasting weapons. Dealing with landmines, and increasingly other forms of ERW remains an important component of the process of freeing Afghans from the consequences of war. Clearing areas and declaring districts free of landmines doesn't just free up the way for further development, but it sends a powerful message that conflict has moved on and that people can take a more optimistic view of the future.

This strategic plan sets out the overall purpose of the MAPA during the period 1395-1399 (1 April 2016-31 March 2020), the desired results of its operations and activities, and the overall means by which it will achieve its goals and objectives. The main body of this document describes the current mine action context as it affects the MAPA and sets out the strategic goals and objectives of the programme. Detail about action plans, means of checking progress and key responsibilities are set out in the strategic planning matrices in Annex A. Operational managers should develop more detailed plans relating to specific activities and actions within their own areas of responsibility.

Circumstances change over time in ways that may have great significance for the MAPA. It is important that the strategic planning system in Afghanistan has the flexibility to be able to respond, adapt and adjust the plan in light of those changing circumstances. A robust review process is part of this plan allowing strategic leaders, managers and stakeholders to consider the continuing suitability and validity of the plan at regular intervals, and when changing circumstances make it sensible to do so, and to take appropriate action to keep the plan on track so as to deliver the maximum benefits to the people of Afghanistan. 


\section{Vision, mission, goals and strategic objectives}

\subsection{Vision}

A country free from landmines and explosive remnants of war (ERW) where people and communities live in a safe environment conducive to national development and where landmine and ERW survivors are fully integrated into society and thus have their rights and needs recognized and fulfilled.

\subsection{Mission}

A mine action programme that delivers support of such efficiency and self-evident effectiveness, and benefits of such recognized value to civilian protection and the wider development of Afghanistan, that its services are demanded, and paid for, by national government agencies, internationally supported development projects and other programmes, for as long as they are required.

The MAPA is one of the world's largest and longest-established mine action programmes, headed by the Directorate of Mine Action Coordination (DMAC) under the authority of the Afghanistan National Disaster Management Authority (ANDMA). The DMAC is supported by the United Nations Mine Action Centre for Afghanistan (UNMACA) a project of the United Nations Mine Action Service (UNMAS) and works in close partnership with national and international organizations to provide a range of services designed to minimize the impact of mines and ERW left over from decades of conflict.

\subsection{Strategic Goals and objectives}

The NMASP has a total of four goals, 33 objectives and 108 associated action plans. Additional details of action plans, milestones, indicators and timescales are provided in Annex A to this plan.

\subsubsection{Goal 1: Facilitating development}

To establish and maintain confidence that all aspects of MAPA planning, prioritization, operations, monitoring and evaluation are informed by and assessed against the development requirements of the people and government of Afghanistan.

It is the stated intention within the sector that mine action should be 'the precursor to development projects'. In recognition of the importance of this view, considerable efforts have been applied to making it a reality and credible data has been provided to indicate some success in doing so. At the same time, not enough has been done to persuade those outside mine action and involved in development projects to agree.

With this in mind, it is a principle goal for the 1395-1399 (2016-2020) strategic period to ensure that the MAPA improves its own understanding of the relationships between what it does and the outcomes that result, and better communicates the services it provides and how they lead to improved Human Security and socio-economic development. Through improved dialogue with government stakeholders, relevant ministries and other development actors, the MAPA aims to build a greater understanding, amongst all stakeholders, of the services it provides to the wider development sector. At the same time the MAPA intends to increase its own understanding of the needs, expectations and requirements of beneficiaries and those stakeholder groups that are most directly affected by mine action work. 
By identifying specific planned development projects, and assessing the impact of mines and ERW on their implementation, information will be gathered and used to maximize the assistance that is provided for such initiatives, whilst promoting formalized, effective partnerships.

Through improved advocacy efforts, including the provision of reliable supporting information, the MAPA intends to ensure that mine action issues are included in government level development frameworks such as the National Priority Programmes (NPPs) and contribute to Afghanistan's achievement of the Sustainable Development Goals (SDGs). The MAPA will then be in a position to assist with the targeted and efficient mobilization of the resources required to deal with the assessed impact.

\section{Strategic objectives}

1. To identify planned development projects for the next five years, to assess impact of mine/ERW contamination on these, and to mobilize resources to plan clearance operations from 1395-1399 (2016-2020).

2. To include mine and ERW challenges in NPPs, SDGs and other government development frameworks to facilitate safe implementation of development programmes in Afghanistan.

3. To include mine action in the development project policies and Provincial Strategic Plans of key government ministries/entities.

\subsubsection{Goal 2: Engagement with other sectors}

To ensure that ministries, departments and agencies of the Government of Afghanistan, as well as national and international non-governmental organizations and institutions, and private sector stakeholders, remain aware of, and take into account, the significance of the MAPA to their strategies, priorities and activities.

Building on the understanding that mine action is in practice more entrenched with wider issues of development and Human Security than has traditionally been presented, the MAPA has committed to broaden the scope of formal engagement with other sectors. This will be done by ensuring that the MAPA's objectives are structured in such a way that they naturally fall within Government sector remits.

Throughout the 1395-1399 (2016-2020) strategic period the MAPA aims to promote and increase formal engagement with the health, education, social protection and agriculture sectors. Obvious links to infrastructure development projects, as well as agencies and stakeholders seeking to safely exploit natural resources, will be maintained and stronger links will be developed with private enterprises and the security sector.

The MAPA will seek to engage in bilateral agreements with relevant stakeholders in order to map the ways in which mine action activities can be implemented so that they support Good Governance, Rule of Law and Human Rights. These will primarily include government ministries, but likely also UN and other international stakeholders interested in joint programming. In particular, efforts will be made to integrate with government sectors as defined in existing frameworks.

\section{Strategic objectives}

1. To integrate mine action into the education sector.

2. To integrate mine action into the health sector.

3. To integrate mine action into the economic and promoting private sector. 
4. To integrate mine action into the agriculture and rural rehabilitation sector.

5. To integrate mine action into the social protection sector.

6. To integrate mine action into the security sector.

7. To integrate mine action into the good governance, rule of law and human rights sector.

8. To integrate mine action into the infrastructure and natural resources sector.

9. To establish bilateral agreements with regional, UN and international organizations on joint programming.

\subsubsection{Goal 3: The Five Pillars of Mine Action}

The practical activities aimed at directly addressing the obligations made under IHL with respect to landmines and ERW are often categorized under the 'Five Pillars of Mine Action' (clearance, risk education, victim assistance, advocacy and stockpile destruction). Under this strategic plan, the MAPA has elected to set two separate sub-goals encompassing the core activities of the sector, one concerning the preventive functions, and a second the responsive.

Afghanistan remains committed to the fulfilment of its obligations under Article V of the APMBT by its extended deadline - the end of 1401 (March 2023). Meeting those obligations remains an overarching strategic goal. The key tool to do so is the APMBT Extension Request Work Plan which should be read in conjunction with this strategic plan. It sets out a clear pathway to completion of clearance by 1401 (2023) and identifies the funding resources required.

\subsubsection{Goal 3-1: Preventive action to reduce the impact of mines and ERW}

To determine and implement appropriate and effective actions to reduce current and future impacts of ERW on the people and Government of Afghanistan, through survey, clearance, stockpile destruction, mine/ERW risk education and advocacy.

Preventive functions are those that, once implemented, serve to reduce the likelihood of landmine and UXO accidents and remove the negative impacts associated with mine and ERW 'blockages'. Properly defined, planned and implemented preventative actions ensure that mines and ERW no longer pose a threat to the population or inhibit vital development initiatives. Preventive actions typically absorb the most mine action resources and deliver the greatest direct benefit to affected populations.

The overarching intent in this respect is to live up to the commitments that the Government of Afghanistan accepted when it ratified the APMBT. The 2013 extension request was submitted with a detailed work plan on how the country would achieve its obligations under the treaty by 1402 (2023). The plan is an important strategic document that will remain effective and central to mine action in Afghanistan during the 1395-1399 (2016-2020) strategic period.

Such practical activity starts with the adoption of professional mine action standards to guide operators and stakeholders in how to address mine and ERW related issues. The Afghanistan Mine Action Standards (AMAS) have been in place since 1385 (2006) and conform to the principles laid out in the International Mine Action Standards (IMAS). As new methodologies and working practices are developed, IMAS best practices are reviewed, updated and published. It is an important objective for the MAPA to ensure that the AMAS are reviewed and modified in order to allow operators access to the most up-to-date and efficient practices in the sector.

Dealing with the threat entails first properly quantifying the remaining hazard. The MAPA aims to complete the survey of those communities where the level of contamination remains unknown and 
to properly assess and quantify those more recent hazards that result from post-1380 (2001) conflicts. Once a complete picture is available, efficient prioritization combined with good use of the land release process ${ }^{1}$ will ensure that those areas with the greatest impact are addressed first.

Though the ultimate aim is to remove the threat altogether, in the interim, it is important to minimize civilian impact and reduce accident rates. This will be supported through risk education initiatives with a particular focus on child protection. The aim is to mainstream risk education efforts by partnering with government line ministries and utilizing community networks and civil society organizations.

\section{Strategic Objectives}

1. To enhance efforts to raise the funds needed to keep preventative mine action activities on track.

2. To quantify the extent of post-1380 (2001) contamination.

3. To complete survey of remaining non-surveyed communities.

4. To keep the APMBT Extension Request Work Plan on-track.

5. To improve the capacity of the Programme to respond to new types of contamination.

6. To mainstream mine/ERW risk education into the activities of government line ministries, civil society organizations and community networks.

7. To support the Government on destruction of un-recorded sporadic, stockpiled and unserviceable ammunition, and on weapons ammunition management.

8. To reduce civilian casualties resulting from mines and ERW, with a particular focus on the protection of children.

9. To continually update and adopt MAPA policies and procedures, and AMAS in accordance with IMAS.

\subsubsection{Goal 3-2: Responsive actions to mitigate the consequences of mine and ERW accidents}

To determine and implement appropriate and effective actions to reduce the impacts arising from mine and ERW accidents on the people of Afghanistan.

Responsive functions are those that seek to address the direct and indirect consequences of landmine and ERW accidents. Much of this work entails advocacy efforts aimed at ensuring that the rights and needs of victims are addressed in government strategies, policies and department budgets in parallel with those of people with disability more broadly.

A key activity will be to advocate for and support the government in the building of a national disability and victim assistance database. Once established, this will enable an accurate understanding of needs and help to inform appropriate policy decisions and resource allocation.

\section{Strategic Objectives}

1. To advocate and support the Government of Afghanistan in developing a national disability/ victim assistance policy.

2. To advocate for and support relevant line ministries (MoLSAMD, MoPH, MoE, MoWA, MRRD, MoF, MoFA, etc.) in the development of inclusive disability/victim assistance policies and specific strategies.

\footnotetext{
${ }^{1}$ Land release is the process of releasing land contaminated by, or suspected to be contaminated by mines and ERW, through non-technical survey, technical survey and clearance operations
} 
3. To advocate for and support MoLSAMD and other line ministries/institutions in the conduct of a national disability/victim assistance survey.

4. To advocate for and support MoLSAMD, MoPH and other line ministries/institutions in the development of a disability database.

5. To advocate for the allocation of funds for direct service provision for victim assistance/disability activities in light of national line ministry priorities.

\subsubsection{Goal 4: Gender and diversity mainstreaming}

To ensure that all gender and diversity groups participate in, and benefit from, the work of the MAPA, and that the MAPA benefits from the insight and participation of gender and diversity groups in all aspects of its work.

As part of wider government efforts to mainstream gender and diversity sensitive programming, the MAPA aims to update, develop and monitor the results of its gender and diversity policy during the 1395-1399 (2016-2020) strategic planning period.

A new gender and diversity policy will have a broad scope with implementation including the agreement of memoranda of understanding (MoUs) with relevant line ministries as well as the review of IPs' policies on these issues. By setting up dedicated gender and diversity departments within MAPA organizations, with specifically allocated resources the issue will be taken to the next step. The departments will be mandated to ensure that gender- and diversity-sensitive project management is implemented through inclusion of gender and diversity issues at the inception, design, implementation and evaluation stages. It will also ensure that practical activities aim at greater inclusion. These will include the setting of concrete targets on employment, increased focus on capacity building in order to afford such groups greater opportunities for professional advancement, and improved consideration of gender and diversity in coordination mechanisms.

The MAPA will continue to highlight the operational benefits arising from greater inclusion, and media campaigns and social events which bring much needed attention to the importance of the issue. By ensuring that ambitious and achievable targets are set and monitored, the MAPA intends to show real progress on this issue during the five-year strategic planning period.

\section{Strategic Objectives}

1. To develop a MAPA gender and diversity policy.

2. To increase employment of women, people with disabilities, and other marginalized groups in different levels of the MAPA.

3. To promote gender and diversity sensitive project management (identification, design, implementation, impact evaluation).

4. To raise awareness within MAPA and its stakeholders of gender and diversity issues.

5. To improve consideration of gender and diversity in coordination mechanisms (balanced scorecard, post-demining impact assessment etc.).

6. To establish gender and diversity departments (or cells) within MAPA organizations and budget allocation for gender-based activities.

7. To continue capacity building of gender departments and promoting their role in the implementation of the gender and diversity mainstreaming policy. 


\section{NMASP development, approval and endorsement}

This strategic plan was developed with the active involvement of a wide range of stakeholders at every stage. $^{2}$

An initial workshop was held in October 2015 (1394) to consider and discuss:

- The MAPA's background, history and current capabilities and capacities.

- The situation in Afghanistan today and key trends of importance to the MAPA.

- Stakeholder identification and analysis.

- The MAPA's strengths, weaknesses, opportunities and threats.

- Identification and analysis of strategic risks to the MAPA, and development of appropriate goals, objectives and activities in response to those risks.

- Development of appropriate indicators associated with strategic goals and objectives.

- Agreement of next steps in developing the plan through a number of goal-specific working groups.

Through 12 discussion sessions, each of three hours, during November and December 2015 (1394), working groups developed detailed plans for each strategic objective under each goal, including action plans, indicators, timelines, milestones and potential risks. The results of the working group discussions were captured in matrices and circulated for comment amongst the wider stakeholder group. His Excellency State Minister for Disaster Management and Humanitarian Affairs Wais Ahmad Barmak attended the final session of the workshop and gave his personal support and endorsement to the NMASP development process and its importance to the Government of Afghanistan.

At the end of January 2016 (1394), a second workshop was held to review the results of the working group discussions, consider the overall direction and presentation of the plan, and to agree the overall structure and content of the NMASP. Once again, His Excellency the Minister attended the closing session of the workshop and reiterated his personal support and commitment to the programme and the NMASP. This plan has the full support of all stakeholders.

\footnotetext{
${ }^{2}$ A full list of those stakeholders involved in the NMASP development process is provided in Annex B to this plan.
} 


\section{The Strategic Context}

The MAPA was the first humanitarian mine and ERW clearance programme in the world, established in 1368 (1989) under the auspices of UNOCHA. In 1381 (2002), after the international community's intervention in Afghanistan and fall of the Taliban the previous year, the Government of Afghanistan requested UNMAS to manage the United Nations Mine Action Centre for Afghanistan (UNMACA) and provide capacity building support to the Department for Mine Clearance (DMC). In January 2008 (1387), the Government, through the modality of the Inter-Ministerial Board for Mine Action (IMB) re-affirmed the DMC's responsibility for mine action coordination operating under the Afghanistan National Disaster Management Authority (ANDMA) and working jointly with UNMAS and the UNMACA.

ANDMA/DMAC supported by UNMAS/UNMACA has overall responsibility for the policy and guidance of the programme. DMAC and UNMACA staff operating from a Kabul headquarters and seven regional offices across the country, have the responsibility for coordination, planning, prioritization, quality management, capacity development, information management, advocacy, communication and resource mobilization of the programme.

The implementation of mine action activities is carried out by a number of national and international mine action NGOs, commercial demining companies and some line ministries.

\subsection{The political, economic and social situation in Afghanistan \\ 3.1.1 International Humanitarian Law (IHL)}

Afghanistan is a state party to the APMBT and Convention on Cluster Munitions (CCM). It has signed the Convention on Certain Conventional Weapons (CCW) and has acceded to the UN Convention on the Rights of Persons with Disability (CRPD).

\subsubsection{Conflict and insecurity}

Afghanistan has been plagued by war and instability for more than three decades. For the past 14 years, international forces and the Afghan Government have been engaged in almost constant conflict with non-state actors. There has been little progress to date in negotiating a political settlement to the conflict, although recent internationally-supported efforts to initiate peace talks have resulted in some limited progress towards the development of a road map for further direct talks between the Government and non-state armed forces. Afghan society is optimistic that further progress will be forthcoming, although it is realistic to expect that significant steps forward will take some time.

Informal power networks, including ethnic and tribal structures as well as the power-bases associated with former Mujahedeen commanders are significant in shaping Afghan political, social and economic dynamics. A lack of rule of law, particularly in rural areas, has led to local clashes over land and economic resources between various groups contributing to insecurity and providing openings for the insurgency.

The climate of insecurity, and the lack of those opportunities that security brings, have been major drivers in the migration crisis of 1394 (2015/16). While migration is often seen as a problem facing Europe and the countries surrounding Syria, it has immediate and significant consequences for Afghanistan, which is suffering a drain of capable, competent and educated people searching for circumstances in which they can thrive, or at least have the opportunity to improve their lives. The MAPA is partly subject to the vicious cycle that currently makes things worse - good people leave, 
insecurity continues, it is harder for the MAPA to do its work, development is stalled, more people leave. But, like most vicious cycles, if it can be reversed it becomes a virtuous cycle - that is, the more the MAPA can do, the more it encourages development, the less people are inclined to engage in conflict, the fewer people leave, the more capable people return, the easier it becomes for the MAPA to function and so on.

The MAPA sees itself as a neutral element within Afghanistan's wider programmes of recovery and development. The MAPA is engaged in a process of transition to full national ownership, an important step in ensuring the long-term sustainability of the programme, but also something that is likely to be taken as further evidence of the integration of the programme with central government.

\subsubsection{The economic and geographical context}

Afghanistan is one of the poorest countries in the world. Aid has supported much of its economic progress since 1380 (2001) and the Afghan Government remains heavily aid dependent. The Afghan economy is largely founded on agriculture and rural trade; around $85 \%$ of the population is entirely reliant on income from agriculture and livestock. Around $12 \%$ of the country's land is arable of which half is under cultivation. Agriculture and livestock based livelihoods remain largely dependent upon the success of rain-fed crops and pasture.

The physical geography of Afghanistan brings challenges to the MAPA. Much of the country is remote from major infrastructure and population centres, and is only accessible by poor roads. The climate, with cold winters and widespread snow followed by extremely hot summers, imposes limits on when and for how long field work can safely be carried out.

The illicit economy, particularly relating to the cultivation of opium, remains significant. The big hope for the future of the Afghan economy is its potential mineral wealth. Afghanistan has some natural resources and a number of projects, with international investment support, have started to exploit minerals in particular.

Economic development is heavily dependent on access to land that is safe from insecurity and from ERW including landmines and UXO. The most recent MAPA analysis shows that about $77.5 \mathrm{~km}^{2}$ of agricultural land, $361.3 \mathrm{~km}^{2}$ of grazing land, $29 \mathrm{~km}^{2}$ of residential area, $89.6 \mathrm{~km}^{2}$ of roads and other infrastructure and $4.4 \mathrm{~km}^{2}$ of water sources are blocked by the presence of mines and ERW.

\subsubsection{International support}

Afghanistan has enjoyed the committed support of the international community throughout the life of the MAPA, but recent years have seen a significant decline in the level of support provided. The challenges faced by Afghanistan, in achieving the objectives outlined in its APMBT extension request and in its constant battle to facilitate development, are such that it is unreasonable to expect the Government of Afghanistan to overcome them on its own. The following graph shows the funding spent on mine action since 1991. 


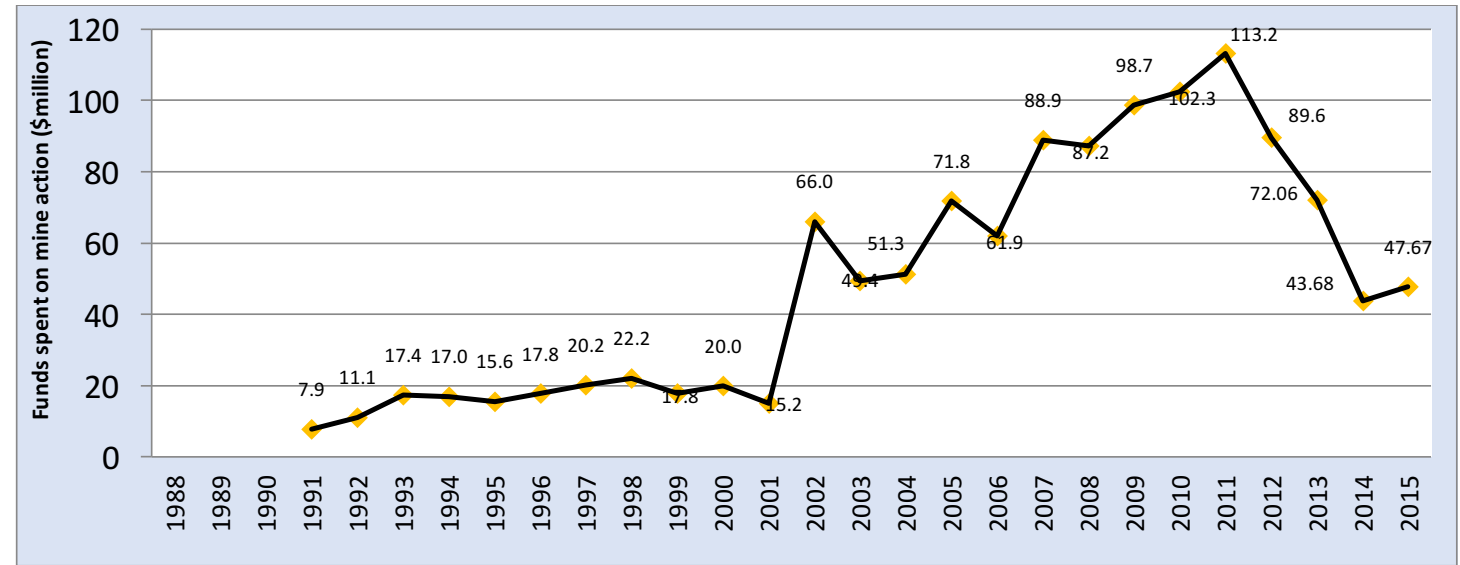

Figure 1: MAPA funding (1991 to 2015)

\subsection{Scope of the problem}

\subsubsection{Landmines and ERW}

Based on current survey results and analysis of achievements to date it is estimated that $78 \%$ of the hazardous land area in Afghanistan has already been released. The $22 \%$ that remains includes 4,293 recorded mine/ERW hazardous areas covering $611 \mathrm{~km}^{2}$ directly impacting 1,570 communities in 254 districts within 32 provinces. ${ }^{3}$ Ongoing conflict across the country means there is a possibility of an increase in contamination.

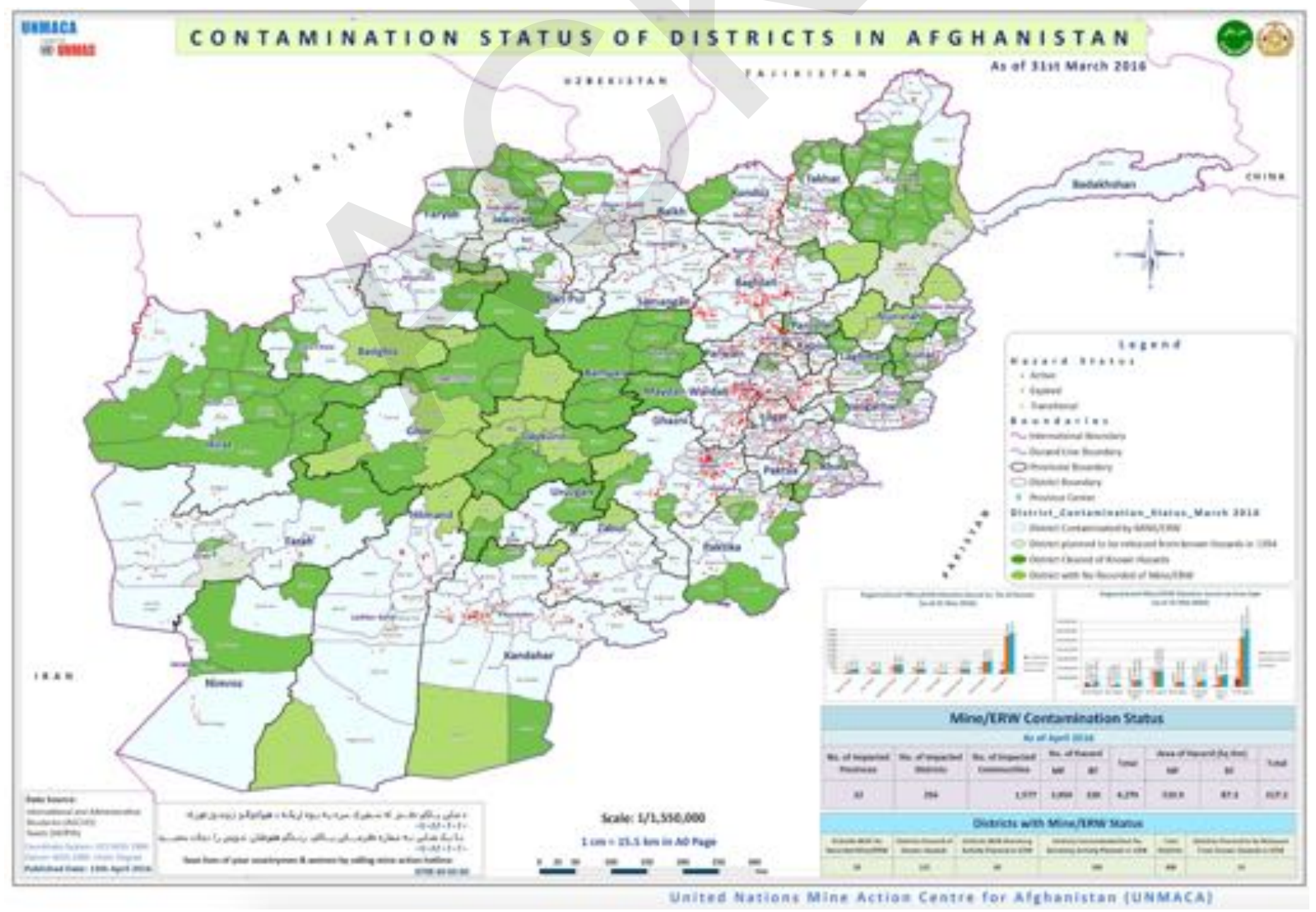

Figure 2: Contamination status across Afghanistan as of April 2016

${ }^{3}$ Figures as at $10^{\text {th }}$ Hoot $1394\left(1^{\text {st }}\right.$ March 2016) 
Of the remaining identified hazardous areas, $44.7 \%$ are associated with anti-tank mines, $40 \%$ with anti-personnel mines and $15.3 \%$ with other ERW. The great majority of the contamination that remains resulted from the wars of 1358 - 1369 (1979-1990), $1370-1373$ (1991-1994), $1374-1380$ (1995-2001), with further material left from the conflicts of 1380 (2001) onward.

Conventional landmines and ERW continued to kill or injure an average of 22 a month during 2015. Over the entire lifetime of the MAPA, ERW have been responsible for the highest number of casualties, followed by anti-personnel landmines. Since the beginning of the programme, 4,879 civilian casualties have resulted from anti-personnel mines, 935 from anti-tank mines, 191 from cluster munitions and 13,730 from other ERW.

\subsubsection{Pressure-plate IEDs}

In recent years the most significant trend has been the increasing significance of pressure-plate improvised explosive devices (PPIEDs) as a source of casualties. If PPIED casualties are considered alongside those of conventional landmines and ERW, the monthly average for 2015 soars to 108 a month. ${ }^{4}$ In 2015, 86\% of newly reported casualties resulted from with PPIEDs.

PPIEDs have been left behind during the ongoing conflict between government forces, international militaries and non-state forces in almost every part of the country. Under the APMBT:

"Anti-personnel mine" means a mine designed to be exploded by the presence, proximity or contact of a person and that will incapacitate, injure or kill one or more persons". "Mine" means a munition designed to be placed under, on or near the ground or other surface area and to be exploded by the presence, proximity or contact of a person or a vehicle."

PPIEDs act in exactly the same way and as such Afghanistan considers clearance of this type of contamination to be part of the Ottawa Treaty challenge.

\subsubsection{Firing Ranges}

International military forces, led by the United States of America, established and used firing ranges for the purposes of training and testing the use of explosive weapons. As is normal on such ranges, a proportion of explosive ordnance fails to function, leaving UXO items and a potential residual risk to civilian lives as and when land is released from military use. Surveys to date have identified more than $1,111 \mathrm{~km}^{2}$ of firing ranges in 18 provinces of the country of which clearance is ongoing. There is the possibility that more firing range contamination will be identified in further surveys.

\subsubsection{Freedom to operate}

As conflicts ebb and flow in different parts of the country the ability of the MAPA to safely deploy personnel and conduct practical work of every kind is constrained. In recent years, mine action personnel have increasingly fallen victim to theft, kidnap and murder at the hands of some antigovernment and criminal groups. The consequence is that survey teams are unable to access parts of the country, and so cannot bring up-to-date understanding of the current nature and extent of contamination, clearance teams cannot get access to some areas impacting communities and risk education teams cannot help affected people take appropriate precautions against becoming victims.

\footnotetext{
${ }^{4}$ According to UNAMA data.
} 


\subsection{MAPA Capacities, capabilities and achievements \\ 3.3.1 Capacities and capabilities}

Around 23 national and international NGOs and 28 commercial demining companies are, or have been, involved in implementation of mine action projects within the MAPA. NGOs have been active in Afghanistan since the start of the programme. The commercial companies (national and international) started working after 1381 (2002), mostly in support of development projects.

Afghanistan benefits from an exceptionally well qualified and experienced resource of technical and operational personnel. A range of factors influence the availability of suitable personnel to support the MAPA's operations including:

- Reductions in the scale of MAPA operations - tending to mean that there are more qualified and experienced people than jobs.

- Insecurity in some parts of the country - leading to a reluctance on the part of some qualified workers to engage in mine action work that might make them a target for AGEs.

- Trends in migration towards north-western Europe - leading to a general reduction in the number of skilled and capable people remaining in the country.

Currently in the MAPA 9,126 people work in the field with another 3,097 persons in support. On balance, and especially in light of reductions in the size of the MAPA, it remains possible to find suitable staff in the numbers required to maintain efficient, quality managed operations.

The MAPA remains capable of carrying out all key functions under the pillars of mine action including:

- Mine/ERW clearance operations - including explosive ordnance disposal (EOD) and PPIED clearance

- Victim assistance

- Mine/ERW risk education

- Advocacy

- Stockpile destruction

Since 2003 the MAPA has been engaged in stockpile management (physical safety and security of munitions and ammunition stockpile management), functions that remain under the responsibility of the Ministry of Defence. The MAPA has provided technical support to other national mine action programmes in the region and a number of MAPA experts serve with other mine action programmes globally.

The UNMACA is a highly capable organization leading the world in many respects. Its quality management system is formally certified against the requirements of ISO 9001, following the adoption of powerful tools to support the management of quality across the MAPA. Most important is the use of the balanced scorecard method to monitor IP performance and now the UNMACA's own internal operations. A number of other national mine action programmes around the world now wish to develop their own similar systems based upon the Afghan model.

MAPA information management revolves around the Information System for Mine Action (IMSMA) with a range of additional analytical tools (including the balanced scorecard) to monitor progress and performance and to support continual improvement processes at programme and operator level. 


\subsubsection{Achievements to date}

Perhaps the greatest achievement of the MAPA has been to continue its battle against the scourge of landmines and ERW even as real battles have been taking place, almost constantly, during the last twenty-seven years. During that time the MAPA has found and destroyed: ${ }^{5}$

- Over 702,483, antipersonnel landmines

- Almost 29,119 anti-tank landmines

- More than 18 million ERW

And it has surveyed, cleared and released:

- Over $1,029 \mathrm{~km}^{2}$ of minefield

- Over $1,031 \mathrm{~km}^{2}$ of battlefield

- Over $140 \mathrm{~km}^{2}$ of firing ranges

More than 21 million people have benefited from risk education during the lifetime of the MAPA.

A total of 117 districts and 2,710 communities have been released from known hazards. Livelihood surveys have collected evidence demonstrating that clearance of land has resulted in significant changes in the economic situation of the local population. Land values have increased, development projects and opportunities have been made possible, and people have found greater peace of mind.

\subsection{Environmental aspects}

The environment is recognized to be an issue of strategic importance to the MAPA. This strategic plan reflects consideration both of the MAPA's effects on the environment within which it works, and the influence of that environment upon the MAPA.

\subsubsection{Environmental impact and the MAPA}

Mine action operations have significant potential to adversely affect the environment. AMAS already reflect some consideration of the environment in their specifications, but it is the intention that more formalized efforts will be made to structure, implement, monitor and evaluate operations in this regard.

To raise the profile of the issue within the MAPA, and to provide a basis for other concrete steps a MAPA-wide environmental policy should be developed and promulgated to all IPs and stakeholders. In addition to further review of existing measures to reduce air, water and ground pollution arising from MAPA activities, four specific areas of focus have been identified:

- Investigating and understanding the impact of mechanical demining units on the environment, especially with respect to soil structure and suitability for follow-on use.

- Improving understanding of the impact of open burning and open detonation techniques for mine/ERW destruction, and the development of further measures to mitigate such impacts.

- Improving understanding of the potential for adverse impact of MAPA activities on heritage sites, and developing measures to reduce such impact.

- Implementing measures to reduce waste (material and energy) arising from MAPA activities.

\footnotetext{
${ }^{5}$ All figures to end of February 2016.
} 
The environment is a cross-cutting issue, relevant to all aspects of MAPA activities, but it is recognized that the greatest potential for impact is found under the survey and clearance functions. As such a specific strategic objective relating to the environment can be found under Goal 3-1.

\subsubsection{Environmental influences on the MAPA}

While the environment is subject to the effects of MAPA activities, so the MAPA is subject to a range of external environmental influences. The physical environment, its topography and geography, as well as the prevailing climate and weather, forms a key part of the context within which MAPA operations takes place.

The environment places constraints on what, where and when the MAPA can carry out some of its work. Environmental circumstances and conditions form a backdrop to MAPA planning, prioritization and implementation and are generally well understood by MAPA staff. Nevertheless, they still represent a source of some uncertainty and give rise to additional costs in relation to some MAPA tasks.

General climatic effects (such as the melting of large quantities of snow on steep slopes), as well as the effects of discrete weather events (such as flooding, landslides), may result in changes to working landscapes and the movement of landmines and ERW into new and unexpected areas.

The MAPA is also subject to the same risks and consequences arising from natural disasters affecting the rest of the Afghan population. At the same time the MAPA is unusually well placed to help respond to such disasters and to reduce the consequences for other parts of Afghan society and the Government. The MAPA has a wide range of practical capabilities including first aid, transportation and mechanical digging and large-scale resources including a workforce used to operating in remote areas with limited or no outside support.

A conference on disaster response was held in Dushanbe, Tajikistan in 1393 (2014) at which a range of recommendations were made relating to the MAPA's readiness to assist with disaster recovery operations. This strategic plan recognizes the importance of the MAPA's abilities in this respect and has set a strategic objective to improve engagement with other key actors in the Afghan disaster response system.

\subsection{Evaluations, assessment and analysis}

A recent external evaluation conducted by Samuel Hall (1393) $(2014)^{6}$ highlighted the strong performance of the programme, but also the somewhat paradoxical situation that despite multi-year success, the sustainability of the MAPA is difficult to predict with confidence.

The evaluation found that huge progress had been made in terms of efficiency, attributable at least in part to the deliberate national ownership of the core coordination functions, but also to a visible decrease in operating costs: a reduction in the cost per $\mathrm{m}^{2}$ of demining came about following the implementation of tightly controlled monitoring systems such as the balanced scorecard. Funding levels continue to have a negative impact on the programme's ability to meet its targets and objectives.

\footnotetext{
6 "Mine Action in Afghanistan: A Success Story in Danger" Samuel Hall 2014.
} 
The report found three major objectives that were yet to be realized: transition to national ownership; gender mainstreaming; and increased focus on impact and victim assistance. Transition to national ownership has not been adopted as a specific strategic objective within this plan, because it is the focus of separate high level commitment within ANDMA and DMAC. The Samuel Hall report found that it was still difficult to assess and quantify indirect development impacts of the MAPA's work. The other second and third objectives identified by Samuel Hall as requiring further attention, as well as the more general need to understand impact better, are explicitly addressed in this plan.

The results of the evaluation align closely with the conclusions that arose from stakeholder discussions and workshops during the strategic planning process. Discussions during the first strategic planning workshop identified a poor understanding of development as it influences mine action and poor engagement with government as the primary sources of strategic risk. Stakeholders were also clear on the importance of addressing gender and diversity issues as fundamental to the programme's future effectiveness, efficiency and credibility with the outside world.

The conclusions and recommendations of the Samuel Hall report provide strong support to the decisions made by strategic planning stakeholders, and for the strategic goals and objectives selected for this NMASP. 


\section{Action plans}

Outline action plans are established for each of the strategic objectives, under the different strategic goals. The action plans set out key steps and stages that will be addressed during the period of this strategic plan. Responsibilities for each individual action are allocated to organizations within the MAPA. Defined responsibilities have been agreed by the relevant ministry or agency in each case. Milestones with target dates are associated with each agreed action. Strategic indicators, relevant risks and intended risk mitigation approaches are defined for each action. Details of all action plans can be found in Annex $A$ to this plan.

Detailed implementation plans, associated with each strategic action, will be developed by the responsible organizations.

\subsection{Facilitating development}

The action plans for the goal of facilitating development are based on an improved awareness, within the MAPA, of the various high level development plans emanating from different ministries and at the collective government level. This will be achieved both by requesting full information from the relevant sources, and by ensuring that the MAPA is represented on key development decision-making bodies, at appropriate levels within government. In particular, it is intended that the DMAC will be represented in future on NPP committees. There are important cross-over linkages with the various action plans relating to 'engagement with other sectors'.

At the same time a more pro-active approach to following up links into the governmental development sector will be adopted, including requests for confirmation that mine action aspects have been taken into account during development planning. This will include the adoption of a more formal approach to checking that mine action considerations have been addressed prior to release of permission to proceed with infrastructure projects. ${ }^{7}$

\subsection{Engagement with other sectors}

The action plans relating to Goal 2 revolve around the development of structured, effective and ongoing relationships with a number of key ministries and other actors that are affected by, or may affect, decision-making and operations within the MAPA. The primary means for doing so will be the signing of MoUs with those ministries and actors, combined with training and awareness raising activities to both increase partner understanding of mine action aspects relevant to their wok, and to enhance MAPA personnel's understanding of partner's needs, expectations and approaches.

The MAPA intends to further increase engagement with actors within the humanitarian mine action sector at the regional and international levels. To that end the strategic plan includes development of a regional coordination and cooperation mechanism, working through the MoFA.

\subsection{Five pillars - preventive actions}

The action plans relating to 'preventive mine action' are based on the improved use of information and awareness at the strategic level. Actions include improved engagement with government

\footnotetext{
${ }^{7}$ In much the same way, for instance, that authorities in many parts of Germany ensure that appropriate risk identification assessment and, where appropriate, mitigation measures have been taken before civil engineering work starts.
} 
agencies and committees (especially in terms of national development plans) and with international donors to improve funding support to the MAPA, to increase awareness of needs and expectations within the MAPA and amongst other stakeholders. Other actions relate to the quantification and definition of hazards resulting from the most recent conflicts, additional training to improve the MAPA's capabilities to integrate development perspectives into all aspects of the practical project cycle, and expansion of risk education functions into line ministries and community networks that have most interaction with mine and ERW issues, as well as to already identified high risk groups such as children. Other proactive actions address the continued commitment to practical field operations, including survey and clearance, to keep the APMBT Extension Request Work Plan on track, and to support government initiatives relating to stockpile management. Polices and standards will be updated as necessary to keep pace with developments in international best practice and in repose to developing circumstances and conditions in Afghanistan as they affect the MAPA.

\subsection{Five pillars - responsive actions}

The programme's responsive activities relate especially to victim assistance, as well as advocacy. Action plans include the establishment of working groups with relevant ministries, support to the development of national policies for persons with disabilities and surveys to gather the data necessary to define more clearly national disability needs, including those relating to mine/ERW issues. Technical capacity development and the monitoring and evaluation of victim assistance functions are included to increase the capability of the MAPA, and associated line ministries, to provide appropriate and effective responsive support.

\subsection{Gender and diversity mainstreaming}

Action in support of gender and diversity mainstreaming will take place at every level within the MAPA. A gender and diversity policy will be developed and adopted in coordination with relevant government ministries and agencies. Networking to raise awareness of the issue, and the achievable options open to mine action organizations, will be carried out in parallel with wider public information campaigns. Existing monitoring systems (such as the balanced scorecard method) that are well established within the MAPA will be adapted to include gender and diversity indicators. Achievable targets, reflecting prevailing circumstances and conditions, will be adopted to support and encourage progress wherever possible. 


\section{Indicators and monitoring}

\subsection{Strategic indicators}

Indicators have been established for each of the strategic objectives and their associated action plans. Maintenance of this framework will be the responsibility of DMAC with the support of UNMACA. The MAPA's information management system will enable appropriate analysis functions, and the dissemination of reports to ensure that up-to-date data are made available to decision-makers. A combination of quantitative and qualitative strategic indicators has been selected including the following:

- Number of development projects requiring mine action support

- Number of development facilitation training sessions conducted

- Total number of $\mathrm{km} 2$ released

- MoUs have been signed with relevant ministries

- Policy papers have been developed

- Inter-agency committees are functioning

The full list of strategic indicators is included in Annex A.

\subsection{Operational indicators}

The MAPA will continue to maintain established operational indicators relating to activities under all five pillars of mine action. Mine action organizations will report in the normal way. Where necessary, and in light of the requirements of this plan, some additional operational indicators may be developed.

\subsection{Monitoring}

Monitoring at the strategic level will be carried out by the DMAC with UNMACA support on the basis of analysis of agreed strategic performance indicators (as detailed in Annex A). A strategic dashboard, kept up-to-date as part of the MAPA information management system, will be established for both management review (in detail) and public communication (summarized).

Monitoring at the operational level is carried out through a combination of visits, inspections and checks of operational activity, as well as rolling analytical techniques using data provided to the DMAC/UNMACA by operating organizations in the normal course of their work. The most significant monitoring tool is the BSC. The UNMACA have been using the BSC approach for the last seven years to monitor IP performance, and have now extended it to allow self-monitoring (of the UNMACA) as well.

The MAPA balanced scorecard approach is highly regarded within the global mine actions sector and is likely to be adopted by a number of other MAPs around the world. The balanced scorecard will be reviewed and adapted as required to reflect the requirements of this plan. 


\section{Risk analysis and management}

\subsection{Strategic Risks \\ 6.1.1 MAPA-wide risks}

Risk can be defined as 'the effect of uncertainty on objectives'. ${ }^{8}$ In identifying strategic risks to the MAPA, planning participants therefore sought to identify sources of the greatest uncertainty.

In assessing the significance and potential consequences of the various different risks facing the project, participants considered whether the risk could:

a) Be a strategic catastrophe that permanently or temporarily stops the programme.

b) Significantly reduce the strategic effectiveness of programme activity.

c) Significantly increase inefficiency in programme activity.

d) Create inconveniences to programme activities.

In parallel, participants considered the likelihood of different events giving rise to adverse consequences.

They concluded that some aspects of operations in Afghanistan that might be perceived to offer the greatest risks, actually did not do so at the strategic level. The most obvious of these are those relating to security. While the security situation can certainly present direct risk of harm to individuals, at the programme level the evidence is that the programme is well able to cope with a high level of general insecurity. Indeed, it has done so, in various different shapes and forms, for almost the entirety of its existence. It is true that a major change in the security situation (for better or worse) could have strategic significance (as discussed below), although participants concluded that such a change was unlikely. More likely was that insecurity would continue at a similar level to today, accepting that the day-to-day characteristics of that insecurity might vary from time to time. Instead, participants identified several other issues as being of strategic risk significance.

\subsubsection{Discontinuities during transition to national ownership}

Transition to national ownership is an important part of the strategic context of the MAPA. The ability of the MAPA to engage with government, to provide a clear picture to international donors, and to be able to manage its own activities, all rely upon a smooth transition to national ownership.

One of the factors mitigating this risk is the elevation of ANDMA to ministerial status and the appointment of a minister with a close interest in the MAPA. Management of the transition process has been elevated from being a strategic goal in this plan (as was first proposed) to management through an independent plan under the supervision of the Minister. Other measures in this strategic plan to mitigate this risk include the adoption of a strategic goal relating to engagement with other sectors. Meanwhile, approval of this strategy by the Government of Afghanistan will significantly reduce strategic risks.

\footnotetext{
${ }^{8}$ ISO 31000:2009 Risk management: Principles and guidelines and ISO Guide 73:2009, definition 1.1
} 


\subsubsection{Changes in Government Policies}

It is not assessed as likely that the MAPA would be subject to a significant and fundamental change in government policy under the government in place at the beginning of 2016. Should there be a change of government, then it is more likely that there might also be a change in policy towards the MAPA. This would be most significant if it resulted in a change in terms of the ministerial ownership of the MAPA, with the uncertainty, discontinuity and changes that would arise.

Such changes might happen and would likely result in reduced effectiveness of the MAPA; itself a source of further risk if it led to a reduction in credibility for the programme. The primary means of mitigating this risk is to focus on the 'facilitating development' and 'engagement with other sectors' strategic goals.

\subsubsection{Significant changes in the security situation/peace talks}

It is a sad fact that Afghanistan has suffered circumstances of insecurity for almost the entire lifetime of the MAPA. The nature of that insecurity has varied from time to time, as have the government, non-state actors and anti-government elements involved. Despite those circumstances the MAPA has managed to continue operations throughout the last 27 years.

Insecurity is not, in itself, a barrier to MAPA operations. Nevertheless, a significant change in the security (for better or worse) could have important implications for the MAPA. An increase in insecurity could mean that MAPA operations are impossible in more parts of the country and reduce the effectiveness of the programme. An inability to operate anywhere in the country would represent a catastrophic impact on the programme, but stakeholders assess the likelihood of such a scenario as low.

A significant improvement in the security situation would also have important implications for the MAPA. Firstly, it is likely that it would be possible to access areas that are currently off limits to MAPA operations, allowing surveying of the current situation and clearance of priority sites, as well as activities under the risk education and victim assistance pillars. It is also likely that peace would attract immediate and widespread international donor support, including for mine action.

Mitigation measures in relation to changes in the situation revolve mostly around an improvement (assessed to be more likely than a major deterioration in security). The primary response would be based upon the excellent Information Management (IM) capacities of the MAPA - the ability to plan additional operations, make use of existing performance data and submit revised proposals for new operations quickly, transparently and with confidence in the validity of planning.

\subsubsection{Significant/unexpected changes in funding levels (donor and/or government)}

An existing downward trend in international funding levels already presents a significant challenge to the MAPA and the achievement of its goals. Despite recent reductions in funding the MAPA has tried to remain on track to meet its 1402 (2023) deadline, but there is a limit to how much efficiency can be improved through cost-cutting and further adoption of methodologies such as land release. During 1393 and 1394 (2014/15 and 2015/16), the MAPA could not achieve its APMBT Extension Request Work Plan clearance targets for the said years and remained 30 percent behind. 


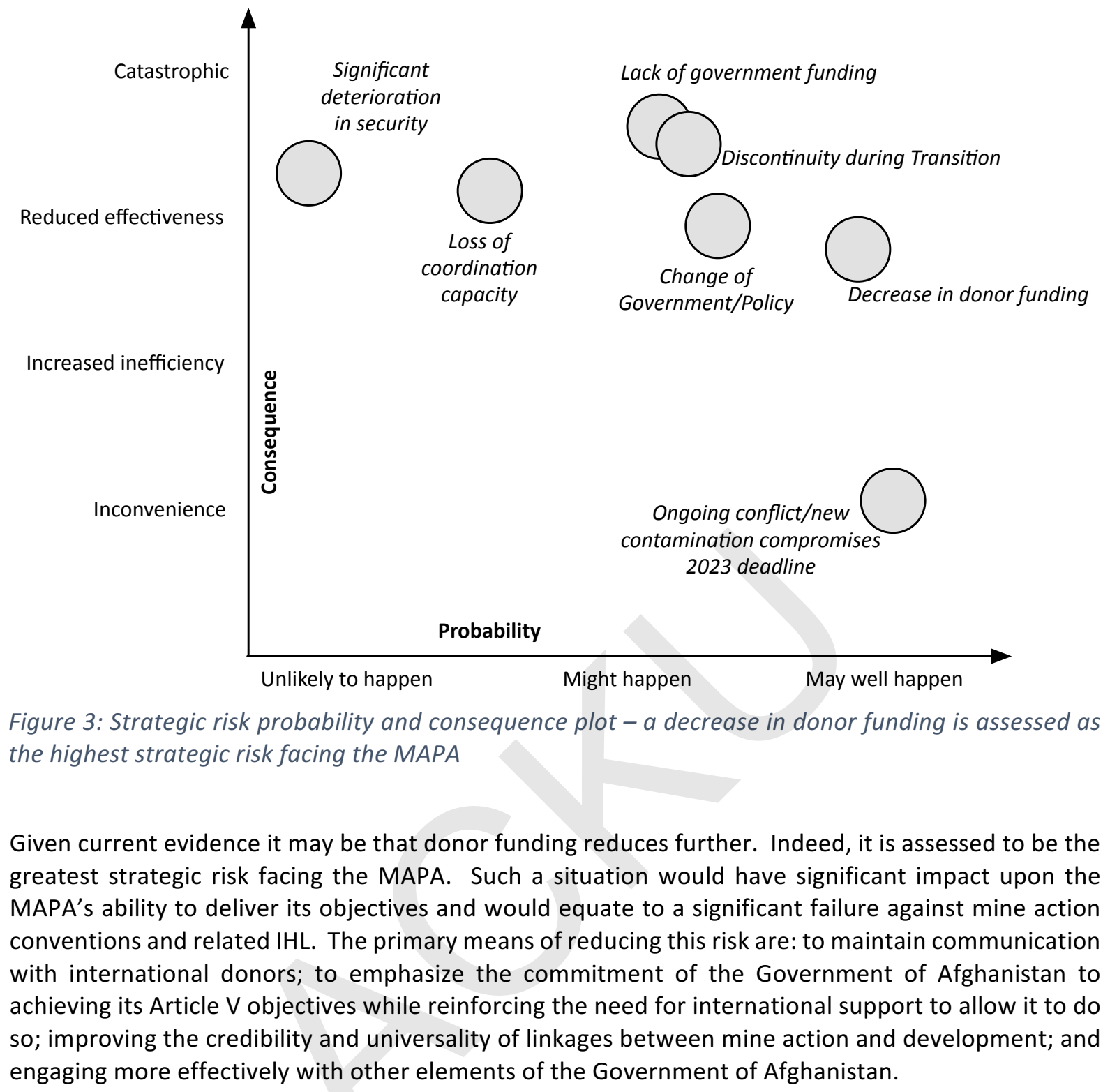

\subsubsection{IEDs and MAPA neutrality}

Strategic planning participants identified the perceived neutrality of the MAPA as an important enabler of its work; allowing teams into areas that might be off-limits to more obviously government agencies. The increasing prevalence of IEDs across Afghanistan, and the potential need for MAPA units to address the threat they represent, may draw the MAPA into current conflict situations.

The MAPA consistently acts and presents itself as a humanitarian, neutral programme which has been given the full support of all past governments of Afghanistan since its inception in 1989, including the Taliban during its period of rule. In addition, it has always had the full support of the Afghan people who recognize the significant impact this national endeavor has on communities throughout the country. Given the localized nature of conflict in Afghanistan, there are incidents which demonstrate that not all actors in the conflict appreciate or recognize the neutrality of the MAPA.

The implications of appearing to take sides when responding to IED threats may be less serious than had previously been thought if the humanitarian purpose is accepted by the community and the IEDs are recognized as abandoned. It is critical for the MAPA to take appropriate and practicable action to 
promote its policy of neutrality to mitigate the consequences of public misperceptions as much as possible. In Afghanistan, all implementing partners must balance the obligation to respond to the public's needs while ensuring a reasonable measure of security for staff and the security risks they face in their work.

\subsubsection{Changes in the conflict/contamination profile compromise ability to meet 2023 APMBT deadline}

In addition to the implications of significant reductions in funding, major changes in the scope and nature of the contamination profile, or an increased inability to access areas of contamination, could compromise the ability of the MAPA to meet its 2023 deadline.

Widespread laying of conventional landmines is not currently anticipated but ongoing war with the involvement of western forces bringing new air-dropped or land service ammunition contamination is a clear risk. The increased use of PPIEDs also gives rise to potential for a significant change in the contamination situation. In 2012, at the time of the APMBT Extension Request Work Plan's development, the scale of PPIED contamination already in existence was an unknown, as was the level to which their use would continue in the following years. A continuation of the current trend of significant use could result in the inability of Afghanistan to achieve its 1402 (2023) deadline. While PPIED numbers are small compared to the numbers of landmines present in Afghanistan at the start of the MAPA (hundreds or possibly thousands of PPIEDs compared with approaching 1 million conventional landmines), the ongoing conflict is preventing their clearance for both reasons of neutrality and accessibility. A comprehensive national survey, for example, would likely prove impossible if Afghanistan remains in a status of armed conflict.

For the moment the MAPA maintains a watch on the PPIED situation and will take appropriate strategic action if and when it is justified to do so.

\subsubsection{Implementation risks}

As part of the strategic planning process, stakeholders identified significant risks at the implementation level. For each of the action plans described in Annex A, risks were identified, assessed and evaluated during the planning process.

Implementation risks that are relevant to many of the objectives and action plans include:

- Long government administration processes

- The effects of ongoing conflict - including lack of access to some areas

- Reducing financial support

- Lack of inclusion of mine action in NPPs and SDGs

- Lack of continuity in key staff members (as they rotate through job functions) in relevant ministries

- Lack of information about post-1380 (2001) conflicts

- New types of ammunition/weapons

- Issues surrounding poor management of stored ammunition

- Lack of female capacities in remote areas

- Cultural/ethnic resistance to some aspects of the MAPA 
At the same time potential mitigation measures were identified and included in the plan. Responsible organizations (as detailed in Annex A) will reflect the relevant mitigation measures when developing their detailed implementation plans for each strategic action.

\subsubsection{Positive outcomes}

It is also important to keep in mind the fact that some risk events could have a positive outcome. Of these, significant steps forward in terms of peace talks and a more stable development environment would perhaps be the most important. Such changes in the situation might not only make it easier for the MAPA to go about its business (and so be more effective and efficient), but also encourage renewed donor support.

\subsection{Risk mitigation strategies}

This strategic plan is based on firm risk management and mitigation approaches. The strategic goals themselves mitigate risk:

- Becoming an organization that is expert at facilitating development, and that integrates development needs into every aspect of its operations, is a primary means of encouraging future support from international donors and national budget using departments and agencies.

- Improving linkages with government departments is intended to increase awareness of the beneficial results arising from well targeted and managed mine action, as well as increasing the MAPA's awareness of the development (and potentially emergency) needs of government departments.

- The strategic goals and objectives associated with the five pillars of mine action are designed to increase stakeholder awareness of the MAPA and to improve linkages between activities and impacts; a primary mechanism to encourage future funding support both internationally and within the national government.

- The gender and diversity goal reflects the importance of demonstrating that the MAPA is serious about addressing all aspects of the needs and expectations of the people of Afghanistan, encouraging further support and commitment from users and funders of the MAPA.

Policies and principles, including those contained within this plan, are used to increase awareness, within and outside the MAPA, of the way in which the programme wishes to go about its business, and the importance of doing so to make a difference to the people of Afghanistan through facilitation of development, delivery of high quality, safe practical services and products and the inclusion of everyone, irrespective of gender, ethnicity or diversity.

Risks associated with acceptance of the NMASP, and its committed and enthusiastic implementation, have been addressed through communication with stakeholders, and their active participation, throughout the strategic planning process. The DMAC and UNMACA have sought to be completely transparent at all times, gathering input from stakeholders, taking decisions where necessary, and explaining the rationale behind those decisions whenever necessary. As a result, the plan enjoys widespread support from MAPA stakeholders.

Risk arises from uncertainty. The DMAC and UNMACA recognize the role played by the management of information and its flows within the programme in reducing uncertainty, and by extension risk. The MAPA information management system is well established at the operational and strategic levels, but further enhancements reflecting the indicators identified in this plan, will further improve information 
flows, enabling stakeholders to play their parts effectively within the programme, and to maintain confidence in the progress and direction of the MAPA.

The MAPA already has a strong and proven emphasis on quality management of practical operations, as well as at the management level. Continued focus will address strategic risks relating to the quality, safety and suitability of the services, processes and products that the MAPA delivers to beneficiaries, government and other stakeholders.

In general terms the MAPA seeks to mitigate strategic risks through:

- Avoidance where possible (such as by keeping clear of those parts of the country that may present too high risk to MAPA personnel).

- Eliminating the causes of risk (e.g. through the removal of those hazardous items that give rise to risk to the people of Afghanistan).

- Reducing the likelihood of risk (by increasing the ability of the MAPA to demonstrate the impact that arises from its operations, so reducing the likelihood of further funding reductions).

- Reducing the consequences of risk (by improving engagement with other sectors to reduce the impact of any one donor or funding source withdrawing or significantly reducing its funding support).

- Sharing risk (through appropriate insurance schemes and through improved cooperation and coordination with relevant government ministries and partners).

Where necessary, and where the MAPA has little opportunity to influence the situation, strategic risk is accepted and reflected in operating policies and procedures. 


\section{Resource mobilization}

MAPA mainly relies on the support of international society for its financial requirement; it receives funds through the Voluntary Trust Fund for Assistance in Mine Action ("the VTF") managed by UNMAS and through bilateral donors. The Government of Afghanistan has provided the coordination capacity of DMAC, in-kind contributions in the form of facilities for implementing partners and the UNMACA, and demining in support of a copper mine development project in Logar province.

The current Article V Extension Request Work Plan is reviewed every year and necessary changes are made to the targets. The funding shortfall from the most recent years is severely affecting targets for the future as areas left behind from previous planning periods are brought forward, placing additional pressure on plans for future years.

\subsection{Resource mobilization strategies}

No programme can survive without funds. The MAPA has seen funding levels decrease over the last four years despite continuing to carry out operations to the highest standards and within a context of continuing urgent social and economic need. The MAPA understands that it needs to demonstrate clearly, credibly and constantly the value of what it does. It is ready to do so, but it is unreasonable to expect the Government of Afghanistan to shoulder the considerable burden on its own. The international community has provided extensive and much appreciated support to help the country achieve a great deal. Now, when the mine action programme can see the end in sight, is not the time to abandon the country to its own devices. Supporting further economic development contributes directly to the potential for peace and stability and indirectly reduces the powerful forces driving the international migration crisis.

Afghanistan suffered from the world's most extensive and impactful mine problem. It is now within several years of being able to declare the complete elimination of that problem. Failure to do so would send entirely the wrong message to those countries fighting against their own mine problems. The Government of Afghanistan is wholly committed to achieving completion against the terms of the $A P M B T$, but doing so is not just a challenge for this one country; it represents a challenge for the global mine action community as well. In that light, the MAPA's primary resource mobilization strategies fall under the two headings of: indisputable value to the development of Afghanistan; and commitment to satisfaction of IHL obligations.

The fundamental underpinning of the programme's justification is its powerful effect on the ability of Afghanistan to develop economically and socially both directly, through the provision of safe land and reduced casualty figures, and indirectly through its important role in demonstrating the end of conflict and the hangover effects of conflict. While available data supports the contention that mine action is a precursor to development, it is clear from discussions during this strategic planning process and the results of recent evaluations, that the MAPA needs to improve its ability to quantify, articulate and communicate the benefits that result from its work. Goal 1 is directly relevant to doing so, as is the increased emphasis found in the strategic objectives and action plans found under all the goals.

For national funders, the MAPA commits to working closely with line ministries and projects within those ministries, to engaging directly with national development planning processes, and to ensuring that 'development is mainstreamed into mine action'.

For international donors, the MAPA will lead the way in demonstrating the value that results from the support provided. The MAPA will implement rigorous assessment processes for every task, will prioritize to maximize benefit within the constraints of the prevailing circumstances and will evaluate 
impact on a rolling basis. The results of impact assessments will inform and improve future prioritization and tasking functions across all pillars of mine action. The DMAC and UNMACA commit to delivering a clear, credible, achievable NMASP that drives efficient, effective and worthwhile activity, of direct importance to the further development of Afghanistan.

\subsection{Resource mobilization projections}

Despite significant efforts, the MAPA has so far been unable to achieve its end goal of making the country free of all mine/ERW hazards, primarily due to the on-gonging conflicts.

When submitting the 10-year extension request in 1391 (2012), the MAPA estimated the amount of $\$ 733.7$ million was necessary to successfully implement the completion plan. The yearly funding projection was made taking into consideration the withdrawal of international forces and expected subsequent diversion of donor interest towards other regions countries as conflicts develop and evolve. A yearly reduction of $10 \%$ compared to the base 1391 (2012) figures was therefore projected.

The plan came into force in 1392 (2013) and in spite of considerable efforts to mobilize resources, the programme was unable to secure the anticipated amounts in the 10 -year plan. The programme received $87 \%$ of requested funds in the first year, $55 \%$ in the $2^{\text {nd }}$ year and $65 \%$ in the third year. Assuming that the trend continues in the same manner, the programme will not be able to achieve its goal by the given 1402 (2023) deadline and will need to submit another extension request.

Despite being underfunded in the first year, the programme was able to achieve its practical targets thanks to efficiency savings within key processes, but in the $2^{\text {nd }}$ and $3^{\text {rd }}$ years, when the funding gap was huge, it was impossible for the programme to achieve its clearance target.

Based on a review of the plan conducted during July 2015, the programme will need a total amount of $\$ 391.7$ million to successfully implement the plan for the next five years. From this amount, $\$ 353.4$ million is required for clearance, $\$ 3.6$ million for survey/EOD, $\$ 5.6$ million for M/ERW risk education, $\$ 4.3$ million for victim assistance and $\$ 24.8$ million for coordination which includes ensuring quality, capacity development, planning and prioritization, information management, advocacy, communications and resource mobilization. 


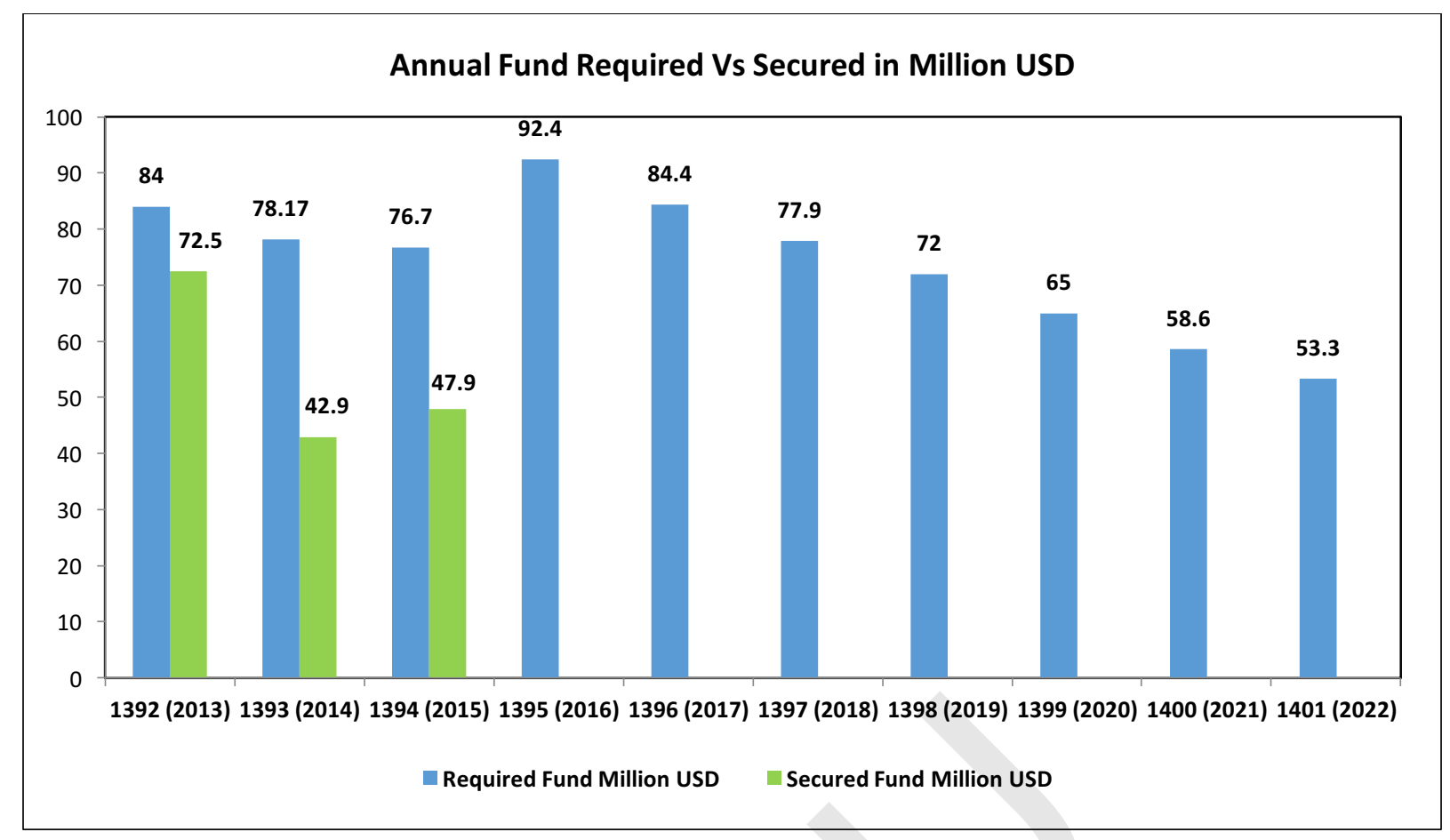

Figure 4: MAPA funding projections to 1401 (2022) and sums secured to 1394 (2015) 


\section{External Evaluation}

The MAPA recognizes the importance of evaluation as a tool to help keep the strategic plan on track, to support improvement of operations at the strategic level and to help high level decision-makers respond to changes in the mine action context. It is MAPA policy that all evaluations should be carried out in accordance with the Development Assistance Committee (DAC) Evaluation Standards and the requirements of IMAS 14.10 (Guide for the evaluation of mine action interventions).

Full strategic evaluations, drawing on external expertise, will be carried out at the mid-term of this plan in 1397 (2018), prior to the end of the plan's lifetime in 1400 (2021) and on other occasions if necessary, in response to changing circumstances and significant events, at the discretion of the DMAC and the Strategic Steering Committee. The results of all evaluations will be made public through the MAPA website.

\subsection{Mid-term evaluation}

The mid-term evaluation will assess the continued validity of the programme's strategic goals and objectives, the extent to which the MAPA is on track to meet targets, and any need to adjust aspects of the plan.

\subsection{Final evaluation}

The final evaluation will assess the overall performance of the MAPA against the plan, during this implementation period, and will provide direct input into the next strategic planning cycle. 


\section{Internal Reviews}

The strategic plan will be reviewed at appropriate intervals to ensure that the plan remains valid, achievable and on track. The MAPA NMASP review committee consists of:

\begin{tabular}{|c|c|c|c|c|c|c|c|c|}
\hline \multicolumn{9}{|c|}{ Steering Committee } \\
\hline \multicolumn{9}{|c|}{ DMAC Director } \\
\hline \multicolumn{5}{|c|}{ Mine Action Advisor to State Minister } & \multicolumn{4}{|c|}{ UNMAS/UNMACA } \\
\hline $\begin{array}{l}\text { VA IP } \\
\text { Director } \\
\text { (tbc) }\end{array}$ & $\begin{array}{c}\text { ATC } \\
\text { Director }\end{array}$ & $\begin{array}{c}\text { DAFA } \\
\text { Director }\end{array}$ & $\begin{array}{c}\text { DDG } \\
\text { Director }\end{array}$ & $\begin{array}{c}\mathrm{HT} \\
\text { Director }\end{array}$ & $\begin{array}{c}\text { MCPA } \\
\text { Director }\end{array}$ & $\begin{array}{c}\text { MDC } \\
\text { Director }\end{array}$ & $\begin{array}{l}\text { OMAR } \\
\text { Director }\end{array}$ & $\begin{array}{c}\text { MRE IP } \\
\text { (tbc) } \\
\text { Director }\end{array}$ \\
\hline \multicolumn{9}{|c|}{ Technical Review Committee } \\
\hline $\begin{array}{ll}\text { 1. } & \mathrm{L} \\
\text { 2. } & \mathrm{L} \\
\text { 3. } & \mathrm{C} \\
\text { 4. } & \mathrm{C} \\
\text { 5. } & \mathrm{L} \\
\text { 6. } & \mathrm{C} \\
\text { 7. } & \mathrm{C} \\
\text { 8. } & \mathrm{L} \\
\text { 9. } & \mathrm{F} \\
\text { 10. } & \mathrm{C} \\
\text { 11. } & \end{array}$ & $\begin{array}{l}\text { NMACA Pla } \\
\text { MAC QM P } \\
\text { MAC Senio } \\
\text { MAC Opera } \\
\text { NMACA OP } \\
\text { NMACA M } \\
\text { NMACA VA } \\
\text { NMACA Ge } \\
\text { ve Nationa } \\
\text { ne MRE IP } \\
\text { ne VA IP re }\end{array}$ & $\begin{array}{l}\text { Ining Man } \\
\text { oject Man } \\
\text { EOD Man } \\
\text { ions Man } \\
\text { R\&D Ma } \\
\text { E Manage } \\
\text { Manager } \\
\text { der Focal } \\
\text { and two I } \\
\text { epresenta } \\
\text { resentati }\end{array}$ & $\begin{array}{l}\text { ger } \\
\text { ser } \\
\text { ser } \\
\text { ser } \\
\text { ger } \\
\text { oint } \\
\text { ernationa } \\
\text { ve }\end{array}$ & Jemining & rganizatio & s represe & atives & \\
\hline
\end{tabular}

The review agenda shall include:

- Status of any actions arising from previous reviews

- Results of strategic monitoring of MAPA performance

- Progress towards achievement of strategic goals and objectives

- Results of evaluations of the programme

- Feedback from stakeholders

- Changes and trends in the strategic context

The plan will be reviewed on the following occasions:

\subsection{Annual review - small scale}

The annual review considers significant trends, their implications for the strategic plan and whether any adjustments are necessary. It takes into account the results of monitoring and any relevant evaluations. The annual review is conducted by the MAPA strategic review committee.

\subsection{Mid-term review - including evaluation results}


A mid-term review is conducted following completion of the mid-term evaluation. The mid-term review is conducted by the MAPA strategic review committee, with participation by other stakeholders as appropriate.

\subsection{End-of-cycle review}

The end-of-cycle review is also the start of the next planning cycle and provides input from this implementation period into the planning process for the next strategic plan. The review includes full stakeholder participation.

\subsection{Other reviews}

Other reviews should be carried out as and when circumstances dictate, in particular on any occasions when there is a significant change in the mine action context. Such circumstances include, but are not limited to:

- Political changes - change of government; major re-organization of the MAPA; significant change in the peace/security situation.

- Economic changes - significant and unexpected change in funding levels (increase or decrease.

- Technical changes - achievement of a major technical objective or changes in the technical environment (such as the widespread introduction of a new type of weapon into the conflict).

- Legal changes - in IHL or to the legal foundation of the MAPA including liability aspects, or other changes in national legislation with important new impacts on the MAPA. 


\section{Conclusion}

The MAPA has managed to succeed, for longer than any other mine action programme, in the face of challenges more severe than those faced by any other programme. It has made great progress, achieved many objectives and made a significant difference to the lives and wellbeing of huge numbers of Afghan women, girls, boys and men. But there are still challenges to face; ones that matter not just to the people of Afghanistan, but to the wider community of mine action and to developed economies around the world.

The MAPA recognizes, accepts and will respond to the challenges facing mine action: the need to understand and demonstrate impact; the need to be better, faster, safer and cheaper at the practical level; the need to maintain commitment to instruments of international humanitarian law. But it cannot do so on its own.

This plan represents another step forward as the MAPA seeks to lead the world of mine action in delivering justified, valuable, efficient and effective mine action processes, services and products. To do so the MAPA needs not only increased support from within Afghanistan, but the continued support of the international donor community. The MAPA understands and respects the demands and expectations of that community and will respond through transparency, accountability, professionalism and the continued efforts of its people.

\section{List of Annexes}
A. Objectives and Action Plans Matrix
B. Stakeholder participants in the strategic planning process
C. Government of Afghanistan References
D. Interfaces with government 


\begin{tabular}{|c|c|}
\hline ANDMA & Afghanistan National Disaster Management Authority \\
\hline ANDS & Afghan National Development Strategy \\
\hline AMAS & Afghanistan Mine Action Standards \\
\hline APMBT & Anti-Personnel Mine Ban Treaty \\
\hline AXO & Abandoned Explosive Ordnance \\
\hline CCM & Convention on Cluster Munitions \\
\hline $\mathrm{CCW}$ & Convention on Certain Conventional Weapons \\
\hline CRPD & Convention on the Rights of Persons with Disabilities \\
\hline DMAC & Directorate for Mine Action Coordination \\
\hline ERW & Explosive Remnants of War \\
\hline IED & Improvised Explosive Device \\
\hline $\mathrm{IHL}$ & International Humanitarian Law \\
\hline IMAS & International Mine Action Standards \\
\hline IP & Implementing Partner \\
\hline MAP & Mine Action Programme \\
\hline MAPA & Mine Action Programme of Afghanistan \\
\hline MoE & Ministry of Education \\
\hline MoF & Ministry of Finance \\
\hline MoFA & Ministry of Foreign Affairs \\
\hline MoLSAMD & Ministry of Labour, Social Affairs Martyrs and Disabled \\
\hline $\mathrm{MoPH}$ & Ministry of Public Health \\
\hline MoWA & Ministry of Women Affairs \\
\hline MRRD & Ministry of Rural Rehabilitation and Development \\
\hline NMASP & National Mine Action Strategic Plan \\
\hline NPPs & National Priority Programmes \\
\hline PPIED & Pressure Plate IED \\
\hline SDG & Sustainable Development Goal \\
\hline SWOT & Strengths, Weaknesses, Opportunities, Threats \\
\hline UNMACA & United Nations Mine Action Centre for Afghanistan \\
\hline UNMAS & United Nations Mine Action Service \\
\hline UXO & Unexploded Ordnance \\
\hline
\end{tabular}


Goal 1: Facilitating development

\begin{tabular}{|c|c|c|c|c|c|c|}
\hline Objective & Action Plan & Responsible Entity & Strategic Indicators & Milestones & Statement of Risk & Risk Mitigation \\
\hline $\begin{array}{l}\text { 1. To identify planned } \\
\text { development projects for the } \\
\text { next five years, to assess } \\
\text { impact of mine/ERW } \\
\text { contamination on these, and } \\
\text { to mobilize resources to plan } \\
\text { clearance operations from } \\
\text { 1395-1399 (2016 - 2020). }\end{array}$ & $\begin{array}{l}\text { 1. Obtain list of planned development } \\
\text { projects for next } 5 \text { years from MoEC } \\
\text { (1395-1399) } \\
\text { 2. Conduct assessment to identify } \\
\text { number of development projects, that } \\
\text { require mine action intervention } \\
\text { 3. Provide written information package to } \\
\text { relevant entities and receive } \\
\text { confirmation/feedback from relevant } \\
\text { entities }\end{array}$ & $\begin{array}{l}\text { 1.1. Ministry of Economy- } \\
\text { Qiam Mukhtar. M\&E dept } \\
\text { 1.2. ANDMA-DMAC through } \\
\text { official request } \\
\text { 2. DMAC/UNMACA (plan, } \\
\text { OPS R\&D/MIS) } \\
\text { 3.1. DMAC/UNMACA. plan } \\
\text { section } \\
\text { 3.2. Relevant entity }\end{array}$ & $\begin{array}{l}\text { 1. Number of development } \\
\text { projects identified as } \\
\text { requiring mine action } \\
\text { 2. Number of projects that } \\
\text { considered mine action } \\
\text { intervention }\end{array}$ & $\begin{array}{l}\text { 1.1. End of April } 2016 \text { for } 5 \\
\text { years project list } \\
\text { 1.2. End of April each year } \\
\text { for annual projects list. } \\
\text { 2. Seven days per project } \\
\text { (after receiving required } \\
\text { information) } \\
\text { 3. Within a month } \\
\text { (obtaining feedback). }\end{array}$ & $\begin{array}{l}\text { - Long government } \\
\text { administration process } \\
\text { - Ongoing conflicts/poor } \\
\text { security } \\
\text { - Lack of donor support for } \\
\text { mine action intervention }\end{array}$ & $\begin{array}{l}\text { - Advocacy and } \\
\text { continual follow-up } \\
\text { with relevant } \\
\text { ministries and donors } \\
\text { - Increase community } \\
\text { liaison } \\
\text { - Convince relevant } \\
\text { donors for MA } \\
\text { importance }\end{array}$ \\
\hline $\begin{array}{l}\text { 2. To include mine and ERW } \\
\text { challenges in NPPs, SDGs and } \\
\text { other government } \\
\text { development frameworks to } \\
\text { facilitate safe } \\
\text { implementation of } \\
\text { development programmes in } \\
\text { Afghanistan. }\end{array}$ & $\begin{array}{l}\text { 1. Inclusion of DMAC/UNMACA on NPP } \\
\text { committees } \\
\text { 2. Addressing of mine/ERW issues under } \\
\text { the SDGs } \\
\text { 3. Consideration of mine/ERW challenges } \\
\text { in other national development } \\
\text { plans/programmes }\end{array}$ & $\begin{array}{l}\text { 1. DMAC/UNMACA with } \\
\text { support from MoEC } \\
\text { 2. Ministry of Economy - } \\
\text { Hewad Niazi . policy dept } \\
\text { 3. ANDMA-DMAC through } \\
\text { official request }\end{array}$ & $\begin{array}{l}\text { 1.1. DMAC/UNMACA } \\
\text { included in NPP } \\
\text { committees } \\
\text { 1.2. MA included in NPPs } \\
\text { 2. MA included in SDGs } \\
\text { 3. MA included in other } \\
\text { national development } \\
\text { plans/programmes }\end{array}$ & $\begin{array}{l}\text { 1. Three months, following } \\
\text { decision of presidential } \\
\text { office regarding number of } \\
\text { revised NPPs } \\
\text { 2. By end of } 2017 \\
\text { 3. Within one month, } \\
\text { following the identification } \\
\text { of new programme of the } \\
\text { relevant entities }\end{array}$ & $\begin{array}{l}\text { - Long government } \\
\text { administration process } \\
\text { - Insufficient resources and } \\
\text { commitment in government } \\
\text { - Weak/inadequate donor } \\
\text { support for mine action } \\
\text { intervention } \\
\text { - Loss of donors support if } \\
\text { mine action not included in } \\
\text { NPPs/SDGs }\end{array}$ & $\begin{array}{l}\text { - Advocacy and } \\
\text { continual follow-up } \\
\text { with relevant } \\
\text { ministries and donors } \\
\text { - Convince relevant } \\
\text { government entities } \\
\text { to consider MA in } \\
\text { their plan/programs } \\
\text { - Continual capacity } \\
\text { building and } \\
\text { development }\end{array}$ \\
\hline $\begin{array}{l}\text { 3. To include mine action in } \\
\text { the development project } \\
\text { policies and Provincial } \\
\text { Strategic Plans of key } \\
\text { government } \\
\text { ministries/entities. }\end{array}$ & $\begin{array}{l}\text { 1. Obtain the agreement of National } \\
\text { Disaster Management Committee } \\
\text { (NDMC) } \\
\text { 2. Obtain official order from Presidential } \\
\text { Office to relevant ministries/entities, in } \\
\text { getting demining certificate before } \\
\text { implementation of all infrastructure } \\
\text { projects } \\
\text { 3. Follow-up on inclusion of mine action } \\
\text { issues in the development project policies } \\
\text { and Provincial Strategic Plans of key } \\
\text { government ministries/entities. }\end{array}$ & $\begin{array}{l}1 \& 2 . \text { State minister for } \\
\text { Disaster Management and } \\
\text { Humanitarian Affairs } \\
\text { (ANDMA) } \\
\text { 3. DMAC/UNMACA }\end{array}$ & $\begin{array}{l}\text { 1. Agreement obtained } \\
\text { from NDMC } \\
\text { 2. Presidential order } \\
\text { obtained } \\
\text { 3. MA issues included in } \\
\text { the policies of } \\
\text { development } \\
\text { projects/Provincial } \\
\text { Strategic Plans }\end{array}$ & $\begin{array}{l}\text { 1. By end of May } 2016 \\
\text { 2. By end of July } 2016 \\
\text { 3. By end of December } \\
2016\end{array}$ & $\begin{array}{l}\text { - Other high priority issues for } \\
\text { government } \\
\text { - Insufficient resources and } \\
\text { commitment in government } \\
\text { - Limited donor commitment } \\
\text { for mine action in } \\
\text { development projects }\end{array}$ & $\begin{array}{l}\text { - Advocacy and } \\
\text { continual follow-up } \\
\text { with relevant } \\
\text { ministries and donors } \\
\text { - Convince relevant } \\
\text { government entities } \\
\text { to consider MA in } \\
\text { their plan/programs } \\
\text { - Advocate MA } \\
\text { importance in } \\
\text { implementation of } \\
\text { Development projects }\end{array}$ \\
\hline
\end{tabular}


Annex A - Objectives and Action Plans Matrix (Continued)

Goal 2: Engagement with other sectors

\begin{tabular}{|c|c|c|c|c|c|c|}
\hline Objective & Action Plan & Responsible Entity & Strategic Indicators & Milestones & Statement of Risk & Risk Mitigation \\
\hline $\begin{array}{l}\text { 1. To integrate mine action } \\
\text { into the education sector }\end{array}$ & $\begin{array}{l}\text { Signing of MoUs with relevant } \\
\text { ministries/entities on: } \\
\text { 1. Further development of curriculum } \\
\text { with MoE } \\
\text { 2. Training of trainers for MoE school } \\
\text { teachers on MRE/VA } \\
\text { 3. The integration of MRE/VA into the } \\
\text { teacher training curriculum } \\
\text { 4. Broadcasting of MRE messages through } \\
\text { mass media with MolC } \\
\text { 5. Broadcasting of MRE messages through } \\
\text { telecommunication companies with } \\
\text { MoICT }\end{array}$ & 1. DMAC/UNMACA & $\begin{array}{l}\text { 1. MoU signed \& } \\
\text { mine/ERW risk education } \\
\text { included in MoE curricula } \\
\text { 2. MoU signed \& } \\
\text { commitment of MoIC } \\
\text { obtained to broadcast } \\
\text { mine/ERW messages } \\
\text { through media } \\
\text { 3. MoU signed with MoICT } \\
\text { and mine/ERW risk } \\
\text { education messages } \\
\text { broadcast regularly }\end{array}$ & $\begin{array}{l}\text { 1. MoU signed by end of } \\
\text { December } 2016 \text { with MoE } \\
\text { and MolC } \\
\text { 2. Subject to revision of } \\
\text { curricula by MoE } \\
\text { 3. Risk education messages } \\
\text { broadcast by MolC by the } \\
\text { end of January } 2017 \\
\text { 4. Risk education messages } \\
\text { broadcast by } \\
\text { telecommunication } \\
\text { companies by the end of } \\
\text { January } 2017\end{array}$ & $\begin{array}{l}\text { - Long government } \\
\text { administration process } \\
\text { - Insufficient resources and } \\
\text { commitment in government }\end{array}$ & $\begin{array}{l}\text { - Advocacy and } \\
\text { continual follow-up } \\
\text { with relevant } \\
\text { ministries and donors }\end{array}$ \\
\hline $\begin{array}{l}\text { 2. To integrate mine action } \\
\text { into the health sector }\end{array}$ & $\begin{array}{l}\text { Signing of MoUs with relevant } \\
\text { ministries/entities on: } \\
\text { 1. Integration of MRE/VA message } \\
\text { delivery in vaccination campaign } \\
\text { 2. Establishment of IMS in DRD-MoPH } \\
\text { and link with HMIS }\end{array}$ & 1. DMAC/UNMACA & $\begin{array}{l}\text { 1. MoU signed \& risk } \\
\text { education materials } \\
\text { disseminated } \\
\text { 2. Database system } \\
\text { established in DRD-MoPH } \\
\text { 3. Data synchronization } \\
\text { mechanism is functional } \\
\text { between IMSMA and DRD- } \\
\text { MoPH }\end{array}$ & $\begin{array}{l}\text { 1. MoU signed by end of } \\
\text { October } 2016 \text { with MoPH } \\
\text { 2. Database is established } \\
\text { by December } 2016 \\
\text { 3. Data synchronization on } \\
\text { quarterly basis }\end{array}$ & $\begin{array}{l}\text { - Long government } \\
\text { administration process } \\
\text { - Insufficient resources and } \\
\text { commitment in government } \\
\text { - Insufficient funding related } \\
\text { to maintaining database } \\
\text { system in MoPH \& publication } \\
\text { of MRE/VA awareness } \\
\text { materials } \\
\text { - Frequent staff rotation in the } \\
\text { government structure }\end{array}$ & $\begin{array}{l}\text { - Advocacy and } \\
\text { continual follow-up } \\
\text { with relevant } \\
\text { ministries and donors } \\
\text { - Continual capacity } \\
\text { building and } \\
\text { development }\end{array}$ \\
\hline $\begin{array}{l}\text { 3. To integrate mine action } \\
\text { into the economic and } \\
\text { promoting private sector }\end{array}$ & $\begin{array}{l}\text { Signing of MoUs with relevant } \\
\text { ministries/entities on: } \\
\text { 1. Inclusion of mine action in } 34 \\
\text { provincial vulnerability profiles } \\
\text { 2. Inclusion of mine action in SDGs } \\
\text { 3. Inclusion of mine action in provincial } \\
\text { development plans } \\
\text { 4. Installation of billboards (municipality, } \\
\text { IDLG) }\end{array}$ & 1. DMAC/UNMACA & $\begin{array}{l}\text { 1. MoUs signed with MoEc } \\
\text { and IDLG }\end{array}$ & $\begin{array}{l}\text { 1. MoUs signed-by mid- } \\
2017\end{array}$ & $\begin{array}{l}\text { - Long government } \\
\text { administration process } \\
\text { - Insufficient resources and } \\
\text { commitment in government } \\
\text { - In-existence of unique } \\
\text { development strategy for SDG }\end{array}$ & $\begin{array}{l}\text { - Advocacy/lobbying } \\
\text { and continual follow- } \\
\text { up with relevant } \\
\text { entities }\end{array}$ \\
\hline $\begin{array}{l}\text { 4. To integrate mine action } \\
\text { into the agriculture and rural } \\
\text { rehabilitation sector }\end{array}$ & $\begin{array}{l}\text { Signing of MoUs with relevant } \\
\text { ministries/entities on: } \\
\text { 1. Inclusion of mine action in all } \\
\text { interventions of MAIL } \\
\text { 2. Inclusion of mine action in all } \\
\text { interventions of MRRD }\end{array}$ & 1. DMAC/UNMACA & $\begin{array}{l}\text { 1. MoUs signed with MAIL } \\
\text { \& MRRD }\end{array}$ & $\begin{array}{l}\text { 1. MoUs signed-by mid- } \\
2017\end{array}$ & $\begin{array}{l}\text { - Long government } \\
\text { administration process } \\
\text { - Insufficient resources and } \\
\text { commitment in government } \\
\text { - Government staff rotation }\end{array}$ & $\begin{array}{l}\text { - Advocacy/lobbying } \\
\text { and continual follow- } \\
\text { up with relevant } \\
\text { entities }\end{array}$ \\
\hline
\end{tabular}




\begin{tabular}{|c|c|c|c|c|c|c|}
\hline $\begin{array}{l}\text { 5. To integrate mine action } \\
\text { into the social protection } \\
\text { sector }\end{array}$ & $\begin{array}{l}\text { Signing of MoUs with relevant } \\
\text { ministries/entities on: } \\
\text { 1. Vocational training with MoLSAMD } \\
\text { 2. Kochies awareness and Protection } \\
\text { 3. Returnes and IDP awareness and } \\
\text { protection } \\
\text { 4. Inclusion of MRE and VA in MoWA } \\
\text { national programmes } \\
\text { 5. inclusion of disability issues with } \\
\text { MoLSAMD } \\
\text { 6. Developing the capacity of mine action } \\
\text { programme actors to respond to natural } \\
\text { disasters }\end{array}$ & 1. DMAC/UNMACA & $\begin{array}{l}\text { 1. MoUs signed with } \\
\text { related ministries/entities }\end{array}$ & $\begin{array}{l}\text { 1. MoUs signed-by end of } \\
\text { December- } 2017\end{array}$ & $\begin{array}{l}\text { - Long government } \\
\text { administration process } \\
\text { - Insufficient resources and } \\
\text { commitment in government } \\
\text { - Government staff rotation }\end{array}$ & $\begin{array}{l}\text { - Advocacy/lobbying } \\
\text { and continual follow- } \\
\text { up with relevant } \\
\text { entities }\end{array}$ \\
\hline $\begin{array}{l}\text { 6. To integrate mine action } \\
\text { into the security sector }\end{array}$ & $\begin{array}{l}\text { Signing of MoUs with relevant } \\
\text { ministries/entities on: } \\
\text { 1. Security issues } \\
\text { 2. Explosive and stockpile management } \\
\text { 3. Maintenance of firing ranges } \\
\text { 4. Establish communication link with } \\
\text { Armed Non-state actors advocating not } \\
\text { to use, stockpile, produce and transfer } \\
\text { mines }\end{array}$ & 1. DMAC/UNMACA & $\begin{array}{l}\text { 1. MoUs signed with } \\
\text { related ministries/entities }\end{array}$ & $\begin{array}{l}\text { 1. MoUs signed-by end of } \\
\text { December- } 2016\end{array}$ & $\begin{array}{l}\text { - Long government } \\
\text { administration process } \\
\text { - Government staff rotation }\end{array}$ & $\begin{array}{l}\text { - Advocacy/lobbying } \\
\text { and continual follow- } \\
\text { up with relevant } \\
\text { entities }\end{array}$ \\
\hline $\begin{array}{l}\text { 7- To include mine action into } \\
\text { good Governance Rule of Law } \\
\text { and Human Rights Sector }\end{array}$ & $\begin{array}{l}\text { 1. Approval of mine action standards by } \\
\text { ANSA (Afghan National Standard Agency) } \\
\text { 2. Inclusion of mine action into AIHRC } \\
\text { policies/programmes }\end{array}$ & 1. DMAC/UNMACA & $\begin{array}{l}\text { 1. MoUs signed with } \\
\text { related ministries/entities }\end{array}$ & $\begin{array}{l}\text { 1. MoUs signed-by end of } \\
\text { December-2017 }\end{array}$ & $\begin{array}{l}\text { - Long government } \\
\text { administration process } \\
\text { - Insufficient resources and } \\
\text { commitment in government } \\
\text { - Government staff rotation }\end{array}$ & $\begin{array}{l}\text { - Advocacy/lobbying } \\
\text { and continual follow- } \\
\text { up with relevant } \\
\text { entities }\end{array}$ \\
\hline $\begin{array}{l}\text { 8. To integrate mine action } \\
\text { into the infrastructure and } \\
\text { natural resources sector }\end{array}$ & $\begin{array}{l}\text { 1. Revision of AMAS related chapter in } \\
\text { consultation with NEPA } \\
\text { 2. Signing of MoU with related } \\
\text { ministries/entities on development and } \\
\text { infrastructure programme/projects } \\
\text { (including all types accessibilities for } \\
\text { Victims/PwDs and others population) }\end{array}$ & 1. DMAC/UNMACA & $\begin{array}{l}\text { 1. NEPA Consulted and } \\
\text { AMAS signed } \\
\text { 2. MoUs signed with } \\
\text { related ministries/entities }\end{array}$ & $\begin{array}{l}\text { 1. AMAS revised by July } \\
2016 \\
\text { 2. MoUs signed-by end of } \\
\text { December-2017 }\end{array}$ & $\begin{array}{l}\text { - Long government } \\
\text { administration process } \\
\text { - Insufficient resources and } \\
\text { commitment in government } \\
\text { - Government staff rotation }\end{array}$ & $\begin{array}{l}\text { - Advocacy/lobbying } \\
\text { and continual follow- } \\
\text { up with relevant } \\
\text { entities }\end{array}$ \\
\hline $\begin{array}{l}\text { 9. To establish bilateral } \\
\text { agreements with regional, } \\
\text { UN and international } \\
\text { organizations on joint } \\
\text { programming }\end{array}$ & $\begin{array}{l}\text { 1. Agreement with MoFA on regional } \\
\text { cooperation and coordination matters } \\
\text { (SAARC, ECO, RECCA, Asia Pacific, Asian } \\
\text { Disaster Preparedness Centre (ADPC) etc. }\end{array}$ & 1. DMAC/UNMACA & $\begin{array}{l}\text { 1. MoUs signed with } \\
\text { related ministries/entities }\end{array}$ & $\begin{array}{l}\text { 1. MoUs signed-by end of } \\
\text { December- } 2017\end{array}$ & $\begin{array}{l}\text { - Long government } \\
\text { administration process } \\
\text { - Insufficient resources and } \\
\text { commitment in government } \\
\text { - Government staff rotation }\end{array}$ & $\begin{array}{l}\text { - Advocacy/lobbying } \\
\text { and continual follow- } \\
\text { up with relevant } \\
\text { entities }\end{array}$ \\
\hline
\end{tabular}


Annex A - Objectives and Action Plans Matrix (Continued)

Goal 3-1: Preventive action to reduce the impact of mines and ERW

\begin{tabular}{|c|c|c|c|c|c|c|}
\hline Objective & Action Plan & Responsible Entity & Strategic Indicators & Milestones & Statement of Risk & Risk Mitigation \\
\hline $\begin{array}{l}\text { 1. To enhance efforts to raise } \\
\text { the funds needed to keep } \\
\text { preventative mine action } \\
\text { activities on track. }\end{array}$ & $\begin{array}{l}\text { 1. Place MA as a permanent agenda point } \\
\text { for NDMC semi-annual committee } \\
\text { meetings } \\
\text { 2. Send an official letter to all donors } \\
\text { through high-rank government } \\
\text { authorities } \\
\text { 3. Conduct donor workshops on annual } \\
\text { basis in Kabul to emphasize the funding } \\
\text { needs of and attract donor support } \\
\text { 4. Hold regular meetings and share } \\
\text { information with donor agencies } \\
\text { 5. Bring new donors on-board through } \\
\text { advocacy } \\
\text { 6. Develop new fundraising strategy }\end{array}$ & $\begin{array}{l}\text { 1. DMAC-ANDMA } \\
\text { 2. DMAC-ANDMA } \\
\text { 3. UNMAS/UNMACA/DMAC } \\
\text { 4. UNMAS/UNMACA/DMAC } \\
\text { 5. UNMAS/UNMACA/DMAC } \\
\text { 6. UNMAS/UNMACA/DMAC } \\
\text { /IPs }\end{array}$ & $\begin{array}{l}\text { 1. MA placed in } \\
\text { government agenda during } \\
10 \text { semi-annual committee } \\
\text { meetings } \\
\text { 2. Official letters } \\
\text { submitted to donors } \\
\text { 3. Five annual donor } \\
\text { workshops conducted in } \\
\text { Kabul } \\
\text { 4. Ad-hoc meetings } \\
\text { information sharing } \\
\text { sessions held } \\
\text { 5. Five new donors } \\
\text { contacted through } \\
\text { advocacy }\end{array}$ & $\begin{array}{l}\text { 1. End of March-2016 } \\
\text { 2. End of March-2016, 17, } \\
\text { 18, } 19 \text { and } 20 \\
\text { 3. September each year } \\
\text { 4. As per the requirement } \\
\text { 5. One donor per year }\end{array}$ & $\begin{array}{l}\text { - Changes in donor priority } \\
\text { - Change of donors funding } \\
\text { channel } \\
\text { - Weak government } \\
\text { commitment } \\
\text { - Ongoing conflict }\end{array}$ & $\begin{array}{l}\text { - Advocacy/lobbying } \\
\text { and continual follow- } \\
\text { up with relevant } \\
\text { donors and } \\
\text { government bodies }\end{array}$ \\
\hline $\begin{array}{l}\text { 2. To quantify the extent of } \\
\text { post-1380 (2001) } \\
\text { contamination. }\end{array}$ & $\begin{array}{l}\text { 1. Establish information-sharing } \\
\text { mechanism with ANSF and international } \\
\text { military forces to obtain data on recent } \\
\text { conflicts } \\
2 \text {. Survey and recording of contaminated } \\
\text { areas as a result of recent conflicts }\end{array}$ & $\begin{array}{l}\text { 1. UNMAS/UNMACA/DMAC } \\
\text { 2. IPs/UNMACA/DMAC }\end{array}$ & $\begin{array}{l}\text { 1. Information sharing } \\
\text { mechanism established } \\
\text { 2. Post-2001 } \\
\text { contamination is recorded } \\
\text { on a systematic basis }\end{array}$ & $\begin{array}{l}\text { 1. By the end of June } 2016 \\
\text { 2. End of every month }\end{array}$ & $\begin{array}{l}\text { - Ongoing conflict } \\
\text { - Lack of proper information } \\
\text { on post } 2001 \text { conflict areas } \\
\text { - Inaccessibility due to security } \\
\text { constraint }\end{array}$ & $\begin{array}{l}\text { - Advocacy and } \\
\text { continual follow-up } \\
\text { and provision of } \\
\text { technical support to } \\
\text { relevant ministries } \\
\text { - Conduct proper } \\
\text { community liaison on } \\
\text { security constraints }\end{array}$ \\
\hline $\begin{array}{l}\text { 3. To complete survey of } \\
\text { remaining non-surveyed } \\
\text { communities. }\end{array}$ & $\begin{array}{l}\text { 1. Complete MEIFCS/ Non-Technical } \\
\text { Survey (NTS) of the remaining } \\
\text { communities }\end{array}$ & $\begin{array}{l}\text { 1. IPs/UNMACA/DMAC and } \\
\text { UNMAS }\end{array}$ & $\begin{array}{l}\text { 1. Certificate of survey } \\
\text { completion from each } \\
\text { individual remaining } \\
\text { community is obtained }\end{array}$ & 1. End of every month & $\begin{array}{l}\text { - Ongoing conflict } \\
\text { - Inaccessibility due to security } \\
\text { constraint } \\
\text { - Poor information source }\end{array}$ & $\begin{array}{l}\text { - Conduct proper } \\
\text { community liaison on } \\
\text { security constraints } \\
\text { and obtaining } \\
\text { required information }\end{array}$ \\
\hline $\begin{array}{l}\text { 4. To keep the APMBT } \\
\text { Extension Request Work Plan } \\
\text { on-track. }\end{array}$ & $\begin{array}{l}\text { 1. Review the APMBT Extension Request } \\
\text { Work Plan } \\
\text { 2. Hold regular updates for stakeholders } \\
\text { 3. Meet the target of the APMBT } \\
\text { Extension Request Work Plan }\end{array}$ & $\begin{array}{l}\text { 1. MBT review committee } \\
\text { 2. UNMACA/DMAC } \\
\text { 3. UNMACA/DMAC/IPs }\end{array}$ & $\begin{array}{l}\text { 1. MBT plan is reviewed } \\
\text { annually } \\
\text { 2. Revised MBT plans are } \\
\text { shared with all } \\
\text { stakeholders } \\
\text { 3. } 276 \mathrm{sq} \mathrm{km} \text { area released }\end{array}$ & $\begin{array}{l}\text { 1. Every year (July to } \\
\text { September) } \\
\text { 2. Every November } \\
\text { 3. By the end of } 2020\end{array}$ & $\begin{array}{l}\text { - Ongoing conflict } \\
\text { - Newly recorded hazards of } \\
\text { legacy contamination + post } \\
2001 \\
\text { - In-sufficient resources }\end{array}$ & $\begin{array}{l}\text { - Further } \\
\text { improvement of } \\
\text { fundraising through } \\
\text { UNMAS and DMAC }\end{array}$ \\
\hline
\end{tabular}




\begin{tabular}{|c|c|c|c|c|c|c|}
\hline $\begin{array}{l}\text { 5. To improve the capacity of } \\
\text { the Programme to respond } \\
\text { to new types of } \\
\text { contamination. }\end{array}$ & $\begin{array}{l}\text { 1. Provide training as per requirements } \\
\text { 2. Update training packages to cover new } \\
\text { challenges }\end{array}$ & $\begin{array}{l}\text { 1. UNMACA/DMAC/IPs } \\
\text { 2. IP's with support from } \\
\text { UNMACA and RS }\end{array}$ & $\begin{array}{l}\text { 1. Training sessions } \\
\text { conducted annually } \\
\text { 2. Training packages } \\
\text { updated twice a year }\end{array}$ & $\begin{array}{l}\text { 1. End of June every year } \\
\text { 2. In each six months }\end{array}$ & $\begin{array}{l}\text { - Insufficient financial } \\
\text { resources } \\
\text { - Newly used ammunitions }\end{array}$ & $\begin{array}{l}\text { - Further } \\
\text { improvement of } \\
\text { fundraising through } \\
\text { UNMAS and DMAC } \\
\text { - Obtaining } \\
\text { information from the } \\
\text { required sources } \\
\text { through Advocacy } \\
\text { /Lobbying }\end{array}$ \\
\hline $\begin{array}{l}\text { 6. To mainstream mine/ERW } \\
\text { risk education into the } \\
\text { activities of government line } \\
\text { ministries, civil society } \\
\text { organizations and community } \\
\text { networks. }\end{array}$ & $\begin{array}{l}\text { 1. Develop a policy paper on the inclusion } \\
\text { of mine/ERW risk education in all projects }\end{array}$ & 1. DMAC & 1. Policy paper developed & 1. End of December 2016 & $\begin{array}{l}\text { - Long government } \\
\text { administration process } \\
\text { - Insufficient resources and } \\
\text { commitment in government } \\
\text { - Government staff rotation }\end{array}$ & $\begin{array}{l}\text { - Advocacy/lobby and } \\
\text { continual follow-up } \\
\text { with relevant entities }\end{array}$ \\
\hline $\begin{array}{l}\text { 7. To support the } \\
\text { Government on destruction } \\
\text { of un-recorded sporadic, } \\
\text { stockpiled and un-serviceable } \\
\text { ammunition, and on } \\
\text { weapons ammunition } \\
\text { management. }\end{array}$ & $\begin{array}{l}\text { 1. Advocacy with ANSF for construction of } \\
\text { standardized ammunition storages. } \\
\text { 2. Support the government in installation } \\
\text { of ammunition recycling technology } \\
\text { 3. Identification of un-recorded sporadic, } \\
\text { stockpiled and un-serviceable } \\
\text { ammunition } \\
\text { 4. Recycling/ Destruction of unserviceable } \\
\text { ammunition }\end{array}$ & $\begin{array}{l}\text { 1. DMAC/UNMACA/ANSF/ } \\
\text { IPs }\end{array}$ & $\begin{array}{l}\text { 1. Standardized } \\
\text { ammunition storages built } \\
\text { by ANSF } \\
\text { 2. Latest ammunition } \\
\text { recycling technology } \\
\text { adopted by Government } \\
\text { 3. Records of stockpiles } \\
\text { identified } \\
\text { 4. Destruction reports }\end{array}$ & $\begin{array}{l}\text { 1. End of December } 2019 \\
\text { 2. End of December } 2019 \\
\text { 3 \&4. Monthly basis }\end{array}$ & $\begin{array}{l}\text { - Lack of information on } \\
\text { Sporadic stockpile } \\
\text { - Poor Ammunition storage } \\
\text { management in ANSF }\end{array}$ & $\begin{array}{l}\text { - Advocacy/lobby and } \\
\text { continual follow-up } \\
\text { with relevant entities } \\
\text { and communities } \\
\text { - Coordination on } \\
\text { capacity building of } \\
\text { ANSF on ammunition } \\
\text { storage management } \\
\text { and maintenance }\end{array}$ \\
\hline $\begin{array}{l}\text { 8. To reduce civilian } \\
\text { casualties resulting from } \\
\text { mines and ERW, with a } \\
\text { particular focus on the } \\
\text { protection of children. }\end{array}$ & $\begin{array}{l}\text { 1. Mainstream child protection issues } \\
\text { into all mine action components } \\
\text { 2. Mainstream child protection issues } \\
\text { including mine/ERW risk education in all } \\
\text { child focused organizations } \\
\text { 3. Advocacy with government to prepare } \\
\text { a policy or a legal document for } \\
\text { prohibition of use of ERW by scrap } \\
\text { business }\end{array}$ & $\begin{array}{l}\text { 1. DMAC/UNMAS/UNMACA } \\
\text { /IPs } \\
\text { 2. DMAC/UNMAS/UNMACA } \\
\text { /IPs/civil society } \\
\text { 3. DMAC/UNMACA/MoJ }\end{array}$ & $\begin{array}{l}\text { 1. Child protection issues } \\
\text { added to relevant AMAS, } \\
\text { SOPs and policies } \\
\text { 2. Mine/ERW key } \\
\text { messages are included in } \\
\text { civil society network } \\
\text { packages } \\
\text { 3. Advocacy meetings on } \\
\text { scrap prohibition policy } \\
\text { held with government }\end{array}$ & $\begin{array}{l}\text { 1. July } 2016 \\
\text { 2. End of December } 2016 \\
\text { 3. Continuous }\end{array}$ & $\begin{array}{l}\text { - Insufficient resources } \\
\text { - Poverty } \\
\text { - Long government } \\
\text { administration process }\end{array}$ & $\begin{array}{l}\text { - Advocacy/lobby and } \\
\text { continual follow-up }\end{array}$ \\
\hline $\begin{array}{l}\text { 9. To continually update and } \\
\text { adopt MAPA policies and } \\
\text { procedures, and AMAS in } \\
\text { accordance with IMAS. }\end{array}$ & $\begin{array}{l}\text { 1. Regular review of Afghanistan Mine } \\
\text { Action Standards (AMAS) by the ANSA } \\
\text { Technical Committee } \\
\text { 2. Endorsement of AMAS by supreme } \\
\text { court of standards GIRoA } \\
\text { 3. Review of policies and procedures }\end{array}$ & $\begin{array}{l}\text { 1. AMAS/ANSA Technical } \\
\text { Committee } \\
\text { 2. UNMACA/ANSA } \\
\text { 3. DMAC/UNMACA }\end{array}$ & $\begin{array}{l}\text { 1\&2. AMAS } \\
\text { reviewed/updated, } \\
\text { translated and endorsed } \\
\text { 3. Policies and procedures } \\
\text { developed }\end{array}$ & $\begin{array}{l}\text { 1 \& 2. Annually } \\
\text { 3. Quarterly basis }\end{array}$ & $\begin{array}{l}\text { - Long government } \\
\text { administration process }\end{array}$ & Advocacy with ANSA \\
\hline
\end{tabular}


Annex A - Objectives and Action Plans Matrix (Continued)

Goal 3-2: Responsive actions to mitigate the consequences of mine and ERW accidents

\begin{tabular}{|c|c|c|c|c|c|c|}
\hline Objective & Action Plan & Responsible Entity & Strategic Indicators & Milestones & Statement of Risk & Risk Mitigation \\
\hline $\begin{array}{l}\text { 1. To advocate and support } \\
\text { the Government of } \\
\text { Afghanistan in developing a } \\
\text { national disability/ victim } \\
\text { assistance policy. }\end{array}$ & $\begin{array}{l}\text { 1. Establishment of working groups led by } \\
\text { MoLSAMD supported by relevant } \\
\text { ministries including MoF, VA/disability } \\
\text { stakeholders and DPOs } \\
\text { 2. Make an action plan for the } \\
\text { development of national disability policy } \\
\text { 3. Establishment of follow-up \& } \\
\text { coordination committee } \\
\text { 4. Allocation of financial resources for } \\
\text { development of national VA/disability } \\
\text { policy (Afghanistan National Policy for } \\
\text { Persons with Disabilities. drafted name) }\end{array}$ & $\begin{array}{l}\text { 1. MoLSAMD with support } \\
\text { from DMAC/UNMACA and } \\
\text { stakeholders } \\
\text { 2. Working group } \\
\text { 3. DMAC/UNMACA } \\
\text { 4. DMAC/UNMACA }\end{array}$ & $\begin{array}{l}\text { 1\&2. Two working groups } \\
\text { established \& an action } \\
\text { plan developed } \\
\text { 3. Financial resources } \\
\text { allocated } \\
\text { 4. National VA/disability } \\
\text { policy finalized \& approved }\end{array}$ & $\begin{array}{l}\text { 1 \& 2. End of April } 2016 \\
\text { 3. End of April } 2016 \\
\text { 4. End of March } 2017\end{array}$ & $\begin{array}{l}\text { - Government staff rotation } \\
\text { - Long government } \\
\text { administration process } \\
\text { - Insufficient resources and } \\
\text { commitment in government }\end{array}$ & $\begin{array}{l}\text { - Advocacy and } \\
\text { continual follow-up } \\
\text { and provision of } \\
\text { technical support to } \\
\text { relevant ministries } \\
\text { and stakeholders }\end{array}$ \\
\hline $\begin{array}{l}\text { 2. To advocate for and } \\
\text { support relevant line } \\
\text { ministries (MoLSAMD, MoPH, } \\
\text { MoE, MoWA, MRRD, MoF, } \\
\text { MoFA, etc.) in the } \\
\text { development of inclusive } \\
\text { disability/victim assistance } \\
\text { policies and specific } \\
\text { strategies. }\end{array}$ & $\begin{array}{l}\text { 1. Support to the inter-ministerial } \\
\text { working group including MoF for } \\
\text { development of sectorial policies and } \\
\text { specific disability/VA strategies } \\
\text { 2. Establishment of follow-up \& } \\
\text { coordination committee } \\
\text { 3. Allocation of financial resources for } \\
\text { development of sectorial VA/disability } \\
\text { policy and strategies } \\
\text { 4. Support the establishment of M\&E and } \\
\text { implementation mechanisms } \\
\text { 5. Conduct } 20 \text { advocacy sessions with } \\
\text { MoF, for financing of VA/disability } \\
\text { policies and strategies }\end{array}$ & $\begin{array}{l}\text { 1. MoLSAMD and other line } \\
\text { ministries with support } \\
\text { from DMAC/UNMACA } \\
\text { 2. MoLSAMD with support } \\
\text { from DMAC/UNMACA } \\
\text { 3. DMAC/UNMACA } \\
\text { 4. MoLSAMD with support } \\
\text { from DMAC/UNMACA } \\
\text { 5. DMAC/UNMACA and } \\
\text { Disability Federation, ACPD } \\
\text { (other disability/VA forums) }\end{array}$ & $\begin{array}{l}\text { 1. Inter-ministerial } \\
\text { VA/disability working } \\
\text { group and follow-up } \\
\text { committee is functional } \\
\text { 2. Financial resources are } \\
\text { allocated } \\
\text { 3. M\&E and working } \\
\text { mechanism developed } \\
\text { 4. MoF support is } \\
\text { enhanced through } 20 \\
\text { advocacy sessions }\end{array}$ & $\begin{array}{l}\text { 1. January to December } \\
\text { 2016 } \\
\text { 2. January to December } \\
2017 \\
\text { 3. End of December } 2017 \\
\text { 4. Four advocacy session } \\
\text { per annum }\end{array}$ & $\begin{array}{l}\text { - Long government } \\
\text { administration process } \\
\text { - Insufficient resources and } \\
\text { commitment in government }\end{array}$ & $\begin{array}{l}\text { - Advocacy and } \\
\text { continual follow-up } \\
\text { with relevant } \\
\text { ministries and } \\
\text { stakeholders }\end{array}$ \\
\hline
\end{tabular}




\begin{tabular}{|c|c|c|c|c|c|c|}
\hline $\begin{array}{l}\text { 3. To advocate for and } \\
\text { support MoLSAMD and other } \\
\text { line ministries/institutions in } \\
\text { the conduct of a national } \\
\text { disability/victim assistance } \\
\text { survey. }\end{array}$ & $\begin{array}{l}\text { 1. Support the establishment of } \\
\text { coordination mechanism for conducting } \\
\text { survey } \\
\text { 2. Development of NDS action plan } \\
\text { including implementation mechanism, } \\
\text { questionnaires, baseline etc. } \\
\text { 3. Support NDS data collection process } \\
\text { 4. Contribute to monitoring process and } \\
\text { quality assurance of NDS }\end{array}$ & $\begin{array}{l}\text { 1. MoLSAMD with Support } \\
\text { from DMAC/UNMACA and } \\
\text { Central Statistics Office } \\
\text { (CSO) } \\
\text { 2. MoLSAMD with Support } \\
\text { from DMAC/UNMACA and } \\
\text { Central Statistics Office } \\
\text { (CSO) } \\
\text { 3. MoLSAMD/CSO with } \\
\text { support from } \\
\text { DMAC/UNMACA } \\
\text { 4. MoLSAMD, MoPH with } \\
\text { support from } \\
\text { DMAC/UNMACA }\end{array}$ & $\begin{array}{l}\text { 1. Four coordination } \\
\text { meetings conducted } \\
\text { 2. NDS action plan \& } \\
\text { survey tools developed } \\
\text { 3. NDS Survey conducted } \\
\text { and data collected } \\
\text { 4. Regular QA carried out }\end{array}$ & $\begin{array}{l}\text { 1. By the end of December } \\
2016 \\
\text { 2. By the end of December } \\
\text { 2016 } \\
\text { 3. Regular support until } \\
\text { the end of } 2017 \\
\text { 4. Regular support until } \\
\text { the end of } 2017\end{array}$ & $\begin{array}{l}\text { - Ongoing conflicts/poor } \\
\text { security } \\
\text { - Long government } \\
\text { administration process } \\
\text { - Insufficient resources and } \\
\text { commitment in government } \\
\text { - Gender sensitive } \\
\text { programming (insufficient } \\
\text { female capacities in remote } \\
\text { areas) }\end{array}$ & $\begin{array}{l}\text { - Advocacy and } \\
\text { continual follow-up } \\
\text { with relevant } \\
\text { ministries and } \\
\text { stakeholders } \\
\text { - Increase community } \\
\text { liaison and inclusion }\end{array}$ \\
\hline $\begin{array}{l}\text { 4. To advocate for and } \\
\text { support MoLSAMD, MoPH } \\
\text { and other line } \\
\text { ministries/institutions in the } \\
\text { development of a disability } \\
\text { database. }\end{array}$ & $\begin{array}{l}\text { 1. Support the revision of disability } \\
\text { degree certification guidelines and tools } \\
\text { 2. Support the development of national } \\
\text { disability/VA database }\end{array}$ & $\begin{array}{l}\text { 1. MoPH, MoLSAMD with } \\
\text { support from } \\
\text { DMAC/UNMACA } \\
\text { 2. MoLSAMD with support } \\
\text { from DMAC/UNMACA }\end{array}$ & $\begin{array}{l}\text { 1. Disability degree } \\
\text { certification } \\
\text { tools/guidelines revised } \\
\text { and approved } \\
\text { 2. Database developed }\end{array}$ & $\begin{array}{l}\text { 1. End of August } 2016 \\
\text { 2. End of December } 2017\end{array}$ & $\begin{array}{l}\text { - Long government } \\
\text { administration process } \\
\text { - Insufficient resources and } \\
\text { commitment in government }\end{array}$ & $\begin{array}{l}\text { - Advocacy and } \\
\text { continual follow-up } \\
\text { with relevant } \\
\text { ministries, } \\
\text { stakeholders and } \\
\text { donors }\end{array}$ \\
\hline $\begin{array}{l}\text { 5. To advocate for the } \\
\text { allocation of funds for direct } \\
\text { service provision for victim } \\
\text { assistance/disability activities } \\
\text { in light of national line } \\
\text { ministry priorities. }\end{array}$ & $\begin{array}{l}\text { 1. Identification of line ministry priorities } \\
\text { 2. Support the development of } \\
\text { VA/disability project documents } \\
\text { 3. Support the implementation of } \\
\text { VA/disability projects of line ministries } \\
\text { 4. Capacity building of line ministry } \\
\text { technical departments } \\
\text { 5. Support M\&E of prioritized } \\
\text { VA/disability projects } \\
\text { 6. Advocacy and support for the } \\
\text { sustainability of VA/disability projects }\end{array}$ & $\begin{array}{l}\text { 1. DMAC/UNMACA with } \\
\text { support from line ministries } \\
\text { 2. DMAC/UNMACA with } \\
\text { support from line ministries } \\
\text { 3. IPs and line ministries } \\
\text { with support from } \\
\text { DMAC/UNMACA } \\
\text { 4. DMAC/UNMACA with } \\
\text { support from line ministries } \\
\text { 5. Line ministries with } \\
\text { support from } \\
\text { DMAC/UNMACA } \\
\text { 6. DMAC/UNMACA with } \\
\text { support from line ministries } \\
\text { and other national } \\
\text { committees }\end{array}$ & $\begin{array}{l}\text { 1. Priorities and projects of } \\
\text { line ministries identified } \\
\text { 2. Regular technical } \\
\text { support provided and } \\
\text { project documents } \\
\text { developed } \\
\text { 3. Identified projects } \\
\text { implemented } \\
\text { 4. Technical capacities } \\
\text { enhanced in line ministries } \\
\text { 5. Regular joint M\&E visits } \\
\text { conducted } \\
\text { 6. Twenty advocacy } \\
\text { sessions conducted }\end{array}$ & $\begin{array}{l}\text { 1. End of December } \\
\text { annually } \\
\text { 2. Ad-hoc basis } \\
\text { 3. Based on the project } \\
\text { plan } \\
\text { 4. Continually } \\
\text { 5. Quarterly } \\
\text { 6. End of } 2020\end{array}$ & $\begin{array}{l}\text { - Insufficient resources and } \\
\text { commitment in government }\end{array}$ & $\begin{array}{l}\text { - Advocacy and } \\
\text { continual follow-up } \\
\text { with relevant } \\
\text { ministries, } \\
\text { stakeholders and } \\
\text { donors }\end{array}$ \\
\hline
\end{tabular}


Annex A - Objectives and Action Plans Matrix (Continued)

Goal 4: Mainstreaming gender and diversity

\begin{tabular}{|c|c|c|c|c|c|c|}
\hline Objective & Action Plan & Responsible Entity & Strategic Indicators & Milestones & Statement of Risk & Risk Mitigation \\
\hline $\begin{array}{l}\text { 1. To develop a MAPA gender } \\
\text { and diversity policy. }\end{array}$ & $\begin{array}{l}\text { 1. MoU with relevant government } \\
\text { organizations } \\
\text { 2. Review gender mainstreaming strategy } \\
\text { 3. Assessment of achievements and } \\
\text { issues regarding gender in mine action } \\
\text { 4. Review of IP's and relevant ministries' } \\
\text { gender-related documents } \\
\text { 5. Develop gender and diversity } \\
\text { mainstreaming policy } \\
\text { 6. Allocate budget to gender and diversity }\end{array}$ & $\begin{array}{l}\text { 1. UNMACA/DMAC } \\
\text { 2. UNMACA, IPs \& DMAC } \\
\text { 3. UNMACA/DMAC, 3rd } \\
\text { Parties } \\
\text { 4. 3rd party entity } \\
\text { 5. UNMACA/GWG } \\
\text { 6. UNMACA/DMAC }\end{array}$ & $\begin{array}{l}\text { 1. MoUs signed } \\
\text { 2. GMS reviewed } \\
\text { 3. Assessment report } \\
\text { completed } \\
\text { 4. Report on reviewed } \\
\text { documents completed } \\
\text { 5. Policy drafted } \\
\text { 6. Budget allocated }\end{array}$ & $\begin{array}{l}\text { 1. End of June } 2016 \\
\text { 2. End of June } 2016 \\
\text { 3. End of Aug } 2016 \\
\text { 4. End of Aug } 2016 \\
\text { 5. End of Sep } 2016 \\
\text { 6. End of May } 2016\end{array}$ & $\begin{array}{l}\text { - Long government } \\
\text { administration procedure } \\
\text { - Lack of budget for 3rd party } \\
\text { assessment } \\
\text { - Unstable situation of } \\
\text { UNMACA }\end{array}$ & $\begin{array}{l}\text { - Continual follow-up } \\
\text { with ministries by } \\
\text { DMAC } \\
\text { - Alternative would be } \\
\text { MAPA Gender } \\
\text { Working Group } \\
\text { - Obtaining } \\
\text { commitment of DMAC }\end{array}$ \\
\hline $\begin{array}{l}\text { 2. To increase employment of } \\
\text { women, people with } \\
\text { disabilities, and other } \\
\text { marginalized groups in } \\
\text { different levels of the MAPA. }\end{array}$ & $\begin{array}{l}\text { 1. Networking with organizations working } \\
\text { in the field of capacity building, disability } \\
\& \text { women } \\
\text { 2. Job preparation trainings by MAPA } \\
\text { 3. Establish and maintain positive } \\
\text { discrimination based on Afghanistan civil } \\
\text { service law } \\
\text { 4. Consider a quota system for women } \\
\text { and people with disabilities } \\
\text { 5. Awareness raising on mine action for } \\
\text { government and non-government } \\
\text { organizations }\end{array}$ & $\begin{array}{l}\text { 1. DMAC/UNMACA \& other } \\
\text { stakeholders } \\
\text { 2. DMAC/UNMACA \& other } \\
\text { stakeholders } \\
\text { 3. DMAC/UNMACA \& other } \\
\text { stakeholders } \\
\text { 4. DMAC/UNMACA \& other } \\
\text { stakeholders } \\
\text { 5. DMAC/UNMACA \& other } \\
\text { stakeholders }\end{array}$ & $\begin{array}{l}\text { 1. Relevant networks } \\
\text { identified and established } \\
\text { 2. Training packages } \\
\text { established and provided } \\
\text { 3. Positive discrimination } \\
\text { based on civil service code } \\
\text { observed } \\
\text { 4. Civil Service quotas } \\
\text { observed } \\
\text { 5. Increased female } \\
\text { participation in MAPA } \\
\text { related events }\end{array}$ & $\begin{array}{l}\text { 1. Starting from Apr } 2016 \\
\text { to end of } 2020 \\
\text { 2. Starting from Apr } 2016 \\
\text { to end of } 2020 \\
\text { 3. End of Dec } 2016 \\
\text { 4. End of Dec } 2016 \\
\text { 5. Starting from Apr } 2016 \\
\text { to end of } 2020\end{array}$ & $\begin{array}{l}\text { - Lack of resources for } \\
\text { networking and lack of } \\
\text { opportunities } \\
\text { - Possible operational clashes } \\
\text { - Lack of willingness by } \\
\text { employers } \\
\text { - Weak rule of law } \\
\text { - Cultural, social and security } \\
\text { barriers/technical capacities }\end{array}$ & $\begin{array}{l}\text { - Advocacy with } \\
\text { donors } \\
\text { - Specific guidelines } \\
\text { - Advocacy \& } \\
\text { continuous } \\
\text { communications } \\
\text { - Awareness } \\
\text { raising/advocacy/enfo } \\
\text { rcement } \\
\text { - Awareness raising } \\
\text { through influential } \\
\text { channels }\end{array}$ \\
\hline $\begin{array}{l}\text { 3. To promote gender and } \\
\text { diversity sensitive project } \\
\text { management (identification, } \\
\text { design, implementation, } \\
\text { impact evaluation). }\end{array}$ & $\begin{array}{l}\text { 1. Use of gender markers ( } 2 a \text { or } 2 b \text { ) as } \\
\text { minimum criteria in evaluation of } \\
\text { proposals } \\
2 \text {. Implementation of gender markers ( } 2 a \\
\text { or } 2 b \text { ) in the field }\end{array}$ & $\begin{array}{l}\text { 1. DMAC \& UNMACA } \\
\text { 2. IPS }\end{array}$ & $\begin{array}{l}\text { 1. Gender markers } \\
\text { considered in evaluations }\end{array}$ & $\begin{array}{l}\text { 1. April } 2016 \\
\text { 2. From June } 2016 \\
\text { continuous }\end{array}$ & $\begin{array}{l}\text { - Cultural, social and security } \\
\text { barriers }\end{array}$ & $\begin{array}{l}\text { - Awareness raising } \\
\text { through different } \\
\text { channels }\end{array}$ \\
\hline $\begin{array}{l}\text { 4. To raise awareness within } \\
\text { MAPA and its stakeholders of } \\
\text { gender and diversity issues. }\end{array}$ & $\begin{array}{l}\text { 1. Awareness raising through mass media } \\
\text { 2. Awareness raising though different } \\
\text { social events } \\
\text { 3. Allocation of funding }\end{array}$ & $\begin{array}{l}\text { 1. DMAC/UNMACA \& IPs } \\
\text { 2. DMAC/UNMACA \& IPs } \\
\text { 3. DMAC/UNMACA \& IPs }\end{array}$ & $\begin{array}{l}\text { 1\&2. Gender in mine } \\
\text { action is widely } \\
\text { understood } \\
\text { 3. Budget secured }\end{array}$ & $\begin{array}{l}\text { 1. Starting from May } 2016 \\
\text { on going } \\
\text { 2. Starting from May } 2016 \\
\text { on going } \\
\text { 3. End of April } 2016\end{array}$ & $\begin{array}{l}\text { - Lack of funding } \\
\text { - Cultural, social and security } \\
\text { barriers }\end{array}$ & $\begin{array}{l}\text { - Advocacy for } \\
\text { fundraising } \\
\text { - Awareness raising } \\
\text { through different } \\
\text { channels }\end{array}$ \\
\hline
\end{tabular}




\begin{tabular}{|c|c|c|c|c|c|c|}
\hline $\begin{array}{l}\text { 5. To improve consideration } \\
\text { of gender and diversity in } \\
\text { coordination mechanisms } \\
\text { (balanced scorecard, post- } \\
\text { demining impact assessment } \\
\text { etc.). }\end{array}$ & $\begin{array}{l}\text { 1. Review and integrate gender and } \\
\text { diversity in balanced scorecard, post- } \\
\text { demining impact assessment and other } \\
\text { forms } \\
\text { 2. Consider representation of gender and } \\
\text { diversity mainstreaming policy in all } \\
\text { coordination events }\end{array}$ & $\begin{array}{l}\text { 1. DMAC/UNMACA (MIS } \\
\text { unit) and IP gender focal } \\
\text { points } \\
\text { 2. DMAC/UNMACA and IPs }\end{array}$ & $\begin{array}{l}\text { 1. Reporting forms and } \\
\text { documents are reviewed \& } \\
\text { adopted according to } \\
\text { gender and diversity } \\
\text { mainstreaming policy } \\
\text { 2. Gender and diversity } \\
\text { mainstreaming policy is } \\
\text { widely disseminated }\end{array}$ & $\begin{array}{l}\text { 1. By the end of June } 2016 \\
\text { 2. Starting from April } 2016 \\
\text { to end of strategic plan }\end{array}$ & $\begin{array}{l}\text { - Cultural restrictions on } \\
\text { practicing/utilizing the forms at } \\
\text { the field level }\end{array}$ & $\begin{array}{l}\text { - Awareness raising } \\
\text { and networking } \\
\text { through influential } \\
\text { bodies at community } \\
\text { level, and continual } \\
\text { follow-up } \\
\text { - Reinforcement of } \\
\text { female field workers }\end{array}$ \\
\hline $\begin{array}{l}\text { 6. To establish gender and } \\
\text { diversity departments (or } \\
\text { cells) within MAPA } \\
\text { organizations and budget } \\
\text { allocation for gender-based } \\
\text { activities. }\end{array}$ & $\begin{array}{l}\text { 1. Inclusion of gender and diversity } \\
\text { departments in organizational structures } \\
\text { 2. Development of specific job } \\
\text { descriptions for the department staff } \\
\text { 3. Hiring of qualified gender and diversity } \\
\text { staff } \\
\text { 4. Allocation of required budget on } \\
\text { annual basis (specific consideration of } \\
\text { gender and diversity activities should } \\
\text { exist in all project budgets) }\end{array}$ & $\begin{array}{l}\text { 1. DMAC/UNMACA and all } \\
\text { IPs }\end{array}$ & $\begin{array}{l}\text { 1. Department is added } \\
\text { into structure } \\
\text { 2. Specific job ToR } \\
\text { developed } \\
\text { 3. At least one qualified } \\
\text { staff is hired } \\
\text { 4. Specific budget } \\
\text { allocated }\end{array}$ & $\begin{array}{l}\text { 1. End of June } 2016 \\
\text { 2. End of May } 2016 \\
\text { 3. End of July } 2016 \\
\text { 4. End of April } 2016\end{array}$ & $\begin{array}{l}\text { - Long government } \\
\text { administration process } \\
\text { - Lack of will from top } \\
\text { management of MAPA } \\
\text { - Difference of opinions } \\
\text { - Donor preferences }\end{array}$ & $\begin{array}{l}\text { - Advocacy with top } \\
\text { governmental } \\
\text { authorities, } \\
\text { lobbying/awareness } \\
\text { raising regarding need } \\
\text { re-structuring to } \\
\text { address gender and } \\
\text { diversity with MAPA } \\
\text { stakeholders }\end{array}$ \\
\hline $\begin{array}{l}\text { 7. To continue capacity } \\
\text { building of gender } \\
\text { departments and promoting } \\
\text { their role in the } \\
\text { implementation of the } \\
\text { gender and diversity } \\
\text { mainstreaming policy. }\end{array}$ & $\begin{array}{l}\text { 1. Convincing of MAPA in considering the } \\
\text { gender and diversity department in } \\
\text { relevant levels of decision making } \\
\text { 2. Conduct periodic capacity assessment } \\
\text { of gender and diversity department staff } \\
\text { 3. Conduct the required capacity building } \\
\text { trainings for gender and diversity } \\
\text { department staff } \\
\text { 4. Establishment of gender and diversity } \\
\text { communication exchange link at national } \\
\text { and international level within mine action } \\
\text { networks } \\
\text { 5. Ensure participation of gender and } \\
\text { diversity staff in mine action events (at } \\
\text { national and international level) } \\
\text { 6. Consider specific budget allocation for } \\
\text { capacity building of gender and diversity } \\
\text { staff }\end{array}$ & $\begin{array}{l}\text { 1. DMAC/UNMACA } \\
\text { 2. MAPA } \\
\text { 3. MAPA } \\
\text { 4. DMAC/UNMACA and IPS } \\
\text { 5-MAPA } \\
\text { 6. MAPA }\end{array}$ & $\begin{array}{l}\text { 1. Gender and diversity } \\
\text { representative is involved } \\
\text { in decision making } \\
\text { 2. Periodic capacity } \\
\text { assessments are } \\
\text { conducted } \\
\text { 3. Identified capacity } \\
\text { building needs are } \\
\text { addressed } \\
\text { 4. Communication } \\
\text { networks established } \\
\text { 5. Gender and diversity } \\
\text { representative is } \\
\text { considered in mine action } \\
\text { events } \\
\text { 6. Specific capacity } \\
\text { building budget is } \\
\text { allocated }\end{array}$ & $\begin{array}{l}\text { 1. July } 2016 \\
\text { 2. Periodic assessments } \\
\text { annually } \\
\text { 3. Ad-hoc } \\
\text { 4. Ongoing process } \\
\text { 5. Ongoing process } \\
\text { 6. Annually }\end{array}$ & $\begin{array}{l}\text { - Weak commitment from } \\
\text { MAPA management level }\end{array}$ & $\begin{array}{l}\text { - Lobbying/advocacy/ } \\
\text { awareness raising }\end{array}$ \\
\hline
\end{tabular}




\section{Annex B - Stakeholder participants in the strategic planning process}

The following organizations participated in the meetings, workshops and discussions leading to the preparation of this strategic plan and its review:

$\begin{array}{ll}\text { AABRAR } & \text { ICRC } \\ \text { AAR - Japan } & \text { KOO } \\ \text { ALSO } & \text { MCPA } \\ \text { AOAD } & \text { MDC } \\ \text { ATC } & \text { MoE } \\ \text { Mine Action Donors } & \text { MoEC } \\ \text { CCD } & \text { MoF } \\ \text { COEWCA } & \text { Mol } \\ \text { DAFA } & \text { MoPH } \\ \text { DAO } & \text { MRRD } \\ \text { DDG } & \text { OMAR } \\ \text { DFID } & \text { SADC } \\ \text { DMAC } & \text { SDA } \\ \text { FODD } & \text { SIG/WRA } \\ \text { FWF } & \text { UNMACA } \\ \text { GICHD } & \text { UNMACA } \\ \text { HALO Trust } & \text { UNMAS } \\ \text { HI } & \text { WDC }\end{array}$




\section{Millennium Development Goals}

Target 23: All emplaced antipersonnel mines destroyed by 1392 (2013) and all other explosive contaminants destroyed by 1394 (2015)

23a: $\quad$ Number of high impacted communities

23a (alt): Hazardous areas

23b: $\quad$ Total number of impacted communities

23c: $\quad$ Number of Afghans directly affected by mines

23d: $\quad$ Number of mine/UXO victims

Target 24: All stockpiled antipersonnel mines destroyed by 1386 (2007) and all other abandoned or unwanted explosive stocks destroyed by 1391 (2012)

24a: $\quad$ Number of stockpiled antipersonnel landmines destroyed

24b: $\quad$ Number of remaining ERW stockpiles to be destroyed

\section{Afghan National Development Strategy (ANDS)}

\section{SECURITY (page 9)}

Unexploded ordnance remains a significant threat to Afghans, with some five thousand citizens either killed or wounded in mine explosions since 1380 (2001/02). Currently only two of the country's 34 provinces are completely clear of land mines.

\section{Chapter 5 (pages 59-61) SECURITY}

Unexploded ordnance remains a significant threat, with some 5,000 citizens either killed or wounded in mine explosions since 1380 (2001).

Currently only two of the country's 34 provinces are completely clear of land mines.

\section{Illegal Armed Groups (P- 60)}

The existence of arms, ammunition caches and mines in different parts of Afghanistan also poses a threat, because opponents of the Government can use them for terrorist operations.

\section{Mines and Explosive Remnants of War (ERW) - Page 61}

Mines and other ERWs are major obstacles to infrastructure and economic reconstruction. The benchmark for locating and destroying all stockpiles of anti-personnel mines was reached in 1386 (October 2007). However the existence of mines and explosives still pose a threat to the lives of four million Afghans. Only two provinces have been completely cleared of mines. Statistics have shown that about 5,000 Afghans have been killed or wounded in mine explosions since 1380 (2001).

Unidentified arms and ammunition caches and mines in different parts of Afghanistan pose an additional threat because opponents of the Government can use these for terrorist operations.

\section{Removing Unexploded Ordnance: - Page 61}

By Jaddi 1389 (end-2010), in line with Afghanistan MDGs, the land area contaminated by mines and unexploded ordnance will be reduced by $70 \%$; by end-2010. all unsafe, unserviceable, and surplus ammunition will be destroyed. The goal is to clear $90 \%$ of all known mine/ERW contaminated areas by 1391 (2012). A further goal is to clear all emplaced antipersonnel mines by 1391 (1 March 2013), in compliance with the Ottawa Convention. A capacity to remove mines and ERWs beyond the 2013 MAPA transition deadline probably will be needed. 
Table 5.1. Integration of the Cross Cutting Issues into the Security Sector (Afghanistan National Development Strategy 67)

\section{Environment}

Implement DIAG and mine/UXO clearance programmes to enhance security that would allow for extensive land to be taken back into use for farming and development.

\section{Security and economic risks (Page 129):}

Continued insecurity has led to the loss of lives and forced people to migrate. Afghanistan is one of the most heavily land-mined countries. In 1385 (2006), landmines killed or injured an average of 61 people per month. The latest survey (NRVA 1386 (Spring 2007)) estimated that 42 percent of the total population was estimated to be poor and living below the CBN poverty line. The incidence of food poverty has been estimated to be even higher. Afghanistan has one of the largest child populations and the smallest proportion of working age populations in the world. Almost 40 percent of the adult population is unemployed.

National Action Plan (2009 - 2013)

PILLAR : SECURITY (Page 200)

SECTOR : SECURITY

\begin{tabular}{|c|c|c|c|c|}
\hline Expected Outcomes & Policy Actions and Activities & Category & Timeframe & $\begin{array}{l}\text { Responsible } \\
\text { Agency }\end{array}$ \\
\hline \multirow[t]{2}{*}{$\begin{array}{l}\text { Reduced level of deaths } \\
\text { and casualties caused by } \\
\text { UXOs, reduce the number } \\
\text { of affected communities } \\
\text { and increased safety } \\
\text { precautions }\end{array}$} & $\begin{array}{l}\text { Clear } 90 \% \text { of all known mine/ERW } \\
\text { contaminated areas by } 1391 \text { (2012). } \\
\text { The goal furthermore is to clear all } \\
\text { emplaced antipersonnel mines by } \\
1391 \text { ( } 1 \text { March 2013) }\end{array}$ & Development & $2008-2013$ & MoFA \\
\hline & $\begin{array}{l}\text { All unsafe unserviceable and surplus } \\
\text { ammunition will be destroyed }\end{array}$ & Development & $2008-2013$ & MoFA, Mol \\
\hline
\end{tabular}




\section{Annex D: Interfaces with Government}

MAPA has the following interfaces with government:

1. In terms of linking mine action with development, DMAC/UNMACA established a communication mechanism with all relevant ministries and independent entities through outreach visits and meetings, as a result:

- Focal points are assigned in almost all relevant ministries

- Quarterly coordination meetings are conducted regularly

- DMAC/UNMACA assess the development projects planned by ministries and development sector based on their requests

2. In regards to inclusion of mine and ERW challenges in strategic documents:

- DMAC/UNMACA a member of task force established by MoEc for MDG 10-year report

- We are in contact with relevant ministries for further inclusion of mine and ERW challenges in PSP, NPPs, SDG, New Deal etc.

3. information dissemination:

- Distribution of the MAPA newsletters and fast facts to all focal points by E-mail

4. Regional level interfaces:

- Provincial Development Committee (PDC) meetings held in governor office

- Sectorial meetings of education, infrastructure and national resources

- Provincial Disaster Management Committee (PDMC) meetings

5. Government support to MAPA:

- Mol support in transfer of explosives to IP sites

- Attestation of IPs explosives (balance) expense report (budget)

- Mol support in securing bankers

- Attestation of progress reports by IPs for their semiannual reports to MoEc.

- Supporting IPs in term of their problems in sites by DMAC

- Supporting the IPs in their introduction to targeted provincial level government

- Travel facilitation of expatriates for any events in Afghanistan (training, workshops)

- ANDMA as government body leading, coordination and support of any events organized nationally, regionally and internationally on MAPA

- $\quad$ DMAC as government body final endorses and processes the land release

- MoFA signs and ratify any treaties and MoU related to Mine Action

- MAPA processes, attests and submits conventions reports through government channels.

- Promoting mine action profile towards cabinet level

- Leading resource mobilization for MAPA

- Leading the endorsement process of National Mine Action strategic planning

- DMAC as a government body finally accept and issue Mine Action organizations accreditation license.

- $\quad$ ANSA support in AMAS finalization process

- DMAC participate the National Security Council's meeting on implementation of the Counter IED Strategy

- DMAC/UNMACA has facilitated inclusion of mine action into provincial development plans

- ANDMA Provincial offices have a mine action focal point that coordinates mine action at provincial level. 